\title{
No-Fault Divorce Reform in the 1950s: The Lost History of the "Greatest Project" of the National Association of Women Lawyers
}

\author{
LAURA OREN
}

This Article is about the lost history of a campaign by the National Association of Women Lawyers (NAWL) to achieve uniform no-fault divorce law reform in the United States. In one form or another, NAWL has existed continuously since before 1911, when it began to publish the Women Lawyers Journal. ${ }^{1}$ From its Progressive era origins until today, NAWL has pursued a women's rights agenda within a professional framework. ${ }^{2}$ Although prior to ratification of the Nineteenth Amendment in 1920

1. Virginia G. Drachman, "The New Woman Lawyer and the Challenge of Sexual Equality in Early Twentieth-Century America," Indiana Law Review 28 (1995): 227, 246. After the first issue of the Journal came out, membership in the club began to climb immediately, going from 20 in 1911 to 76 in 2 years and then to 130 by 1914 . The name of the group was officially changed to the "National Association of Women Lawyers" in 1913. Ibid.

2. See, for example, A. Florence Joyce, "How We Started: NAWL History Chapter I," Women Lawyers Journal 27 (1940-41): 13 (from its inception, NAWL pursued a crusade

Laura Oren is professor emerita at University of Houston Law Center $<$ loren@uh. edu $>$. She thanks Katie Robinson, Legislative Program Director and Communications Officer, and Liza Karsai, Executive Director, of the Uniform Law Commission for access to materials about the drafting of the Uniform Marriage and Divorce Act; former Associate Director of the University of Houston Law Center Library, Mon Yin Lung, and Emily Lawson and Helen Boyce of the University of Houston Law Library for their many courtesies and assistance. She also thanks Bruce Palmer for his many patient and intelligent readings of the article, and Barbara Atwood and Ann Pinchak for their gracious and helpful comments. 
women's suffrage was a key issue for the women lawyers, even then it was far from the only one. Both before and also after suffrage, the Journal reflected the wide-ranging interests of NAWL members, such as legal doctrines in many areas of practice (including divorce), the education of female lawyers, the advancement of women in the profession and in society, and the protection of women and children. ${ }^{3}$ From the 1930s through the 1950s, NAWL also played an active role in two postsuffrage women's rights struggles, the campaigns for female jury service and for the Equal Rights Amendment (ERA). ${ }^{4}$

This history makes it particularly interesting that when the organization undertook what its own chronicler described as "the greatest project NAWL has ever undertaken," it was about divorce law. ${ }^{5}$ In 1947,

of publicity for women in the law or otherwise in the public eye, as in suffrage, business, or politics); "About NAWL," Women Lawyers Journal 101 (2016): 5 (stating that the "mission" of NAWL is to advocate for women in the legal profession and to advance the equality of women under the law).

3. See Women Lawyers Journal 1 (1911-12): 1-8 passim. Compare Women Lawyers Journal 33 (Spring 1947): 1-104 (Katherine Kilpatrick Makielski, "One Hundred Years of Women in the News," 15; N. Ruth Wood, "Marriage and Divorce Laws," 23; Dorothy Kenyon, "United Nations Commission on Status of Women," 37; Matilda Fenberg, "Jury Service for Women," 45; Katherine Kempfer, "Our Congresswomen in Action," 49; Commissioner Caroline K. Simon, "New York State Law Against Discrimination," 51; B. Fain Tucker, "Legal Problems of Artificial Insemination," 57; Ruth F. Major, "National Service Life Insurance," 65; Regene Freund Cohane, "Group Action Among Women," 72; Evelyn G. DeWitt, "Book Reviews," 77; Dorothea Blender, "Review of Legal Periodicals," 78; Grace H. Harte, "Lawyers in the News," 81; and Daphne Robert, "House of Delegates, American Bar Association," 87).

4. See, for example, Matilda Fenberg, "Jury Service for Women," Women Lawyers Journal 36 (1950): 11 (naming jury service as NAWL's number 1 priority). In 1932, NAWL had tried without success to persuade the Supreme Court to grant certiorari in Commonwealth v. Welosky and rule against the exclusion of women from jury service. "Motion of National Association of Women Lawyers for Leave to File Brief as Amicus Curiae and Brief as Amicus Curiae," no. 564 (1931), Commonwealth v. Welosky, 276 Mass. 398, 177 N.E. 656 (1931), cert. den. Welosky v. Commonwealth, 284 U.S. 684 (1932), in Welosky v. Commonwealth of Massachusetts U.S. Supreme Court Transcript of Record with Supporting Pleadings by Joseph Bearak, Laura M. Berrien, and Madge Lee Guard. In 1935, NAWL endorsed the so-called "blanket" Equal Rights Amendment. "Editorial," Women Lawyers Journal 22 (1935-36): 38. In 1948, NAWL members testified on behalf of the amendment before Congress. See "Hearings on the Equal Rights Amendment to the Constitution and Commission on the Legal Status of Women, Before Subcomm. No. 1 of the House Comm. On the Judiciary," 80th Cong., 2d Sess. (1948) (Burnita Shelton Matthews, Chairman, NAWL's Committee on the Legal Status of Women and Rosalie M. Moynahan testifying).

5. Selma Moidel Smith, "A Century of Achievement: The Second 50 Years," Experience 9 (1998-99): 24, 26. 
NAWL voted "to draft and promote a bill that would embody the ideal of no-fault divorce." Instead of the contortions and invitation to perjury in the existing patchwork of fault-based divorce statutes, NAWL sought a uniform model act that would check the evils of migratory divorce and promote national uniformity. It would reflect a more contemporary understanding of the complex causes of marital breakdown, it would operate in the modern spirit of conciliation, and it would be "therapeutic" in its procedure. Despite their belief in its innovative nature, the women lawyers later insisted that the bill that they had designed was "not as revolutionary as appears at first glance." In their view, it was "new chiefly in its attitude and treatment of divorce and in the 'therapeutic approach' which has been adopted." 8 "Otherwise," they said, "the Bill represents a restatement of the best case law and statutory law to be found throughout the forty-eight states." 9

After NAWL formally approved its model bill in 1952, the women lawyers sought consideration for their proposed Uniform Divorce Act by the National Conference of Commissioners on Uniform State Laws (NCCUSL). The conference, an influential private body of distinguished members of the legal profession devoted to developing and promoting uniform model acts for the states to adopt, refused to consider the NAWL proposal unless it was submitted by a section of the American Bar Association (ABA). ${ }^{10}$ It took years for NAWL to overcome that hurdle by successfully leading the way to the establishment of the Family Law Section of the ABA. ${ }^{11}$ Even when NAWL finally was able to submit its proposal, however, NCCUSL continued to bypass the women lawyers and their bill.

The lost history of NAWL's greatest project intersects with three historical inquiries about the 1950s. It interrogates narratives about (1) the history and state of divorce law at that time, (2) the alleged culture of "domesticity" in the decade, and (3) the continuity of women's movement activism in the so-called "doldrums" years. Although there are extensive historical literatures in each of these three areas, to date there has been

6. Ibid.

7. Matilda Fenberg, "Our Proposed Uniform Divorce Bill," Women's Law Journal 44 (1958): 12 .

8. Ibid.

9. Ibid.

10. Matilda Fenberg, "Our Uniform Divorce Bill," Women Lawyers Journal 47 (1961): 12-13. On NCCUSL, see Herbert Jacob, Silent Revolution: The Transformation of Divorce Law in the United States (Chicago: University of Chicago Press, 1988), 62-63; and "History on Uniform State Laws," Women Lawyers Journal 33 (1947): 36.

11. Matilda Fenberg, "The Status of the Proposed Uniform Divorce Bill," Women Lawyers Journal 43 (1957): 10; Smith, "A Century of Achievement: The Second 50 Years," 26, see note 5. 
no scholarly study of NAWL's "no-fault" divorce reform proposal or of NAWL's role as an activist professional and women's rights organization. ${ }^{12}$ This article recovers NAWL's lost history and explores how it fits into the gaps.

In the narratives about the history of divorce law, scholars have established that the changes in the statutory law followed rather than led the long-term rise in American divorce rates that was evident years before the no-fault "revolution" of the 1970s. ${ }^{13}$ They have written about the fascination with "expertise and therapeutic practices" already evident in the $1950 \mathrm{~s}$, and about its eventual defeat in the world of divorce law. ${ }^{14}$ They have reviewed in detail the controversies and compromises surrounding California's pioneering no-fault Family Law Act of 1969 and NCCUSL's Uniform Marriage and Divorce Act (UMDA) of 1970 (as amended in 1971 and 1973). ${ }^{15}$ Scholars debate about how revolutionary

12. For the few references to NAWL in the historical literature, see Leila J. Rupp and Verta A. Taylor, Survival in the Doldrums: The American Women's Rights Movement, 1945 to the 1960s (Columbus, OH: Ohio State University Press, 1990), 46 (including NAWL as one of the "pre-existing core" feminist organizations that sustained the women's movement through the so-called "doldrums" years after the achievement of suffrage); Drachman, "The New Woman Lawyer," 246, see note 1 (describing the special mission of NAWL "to meet the unique professional needs of women lawyers"); Katherine Caldwell, "Not Ozzie and Harriet: Postwar Divorce and the American Liberal State," Law \& Social Inquiry 23 (1998): 1, 39 (noting NAWL support for the Uniform Reciprocal Enforcement of Support Act); Louise B. Raggio, "Women Lawyers in Family Law," Family Law Quarterly 33 (1989): 501, 510 (explaining that when the ABA finally agreed to admit NAWL to the House of Delegates after World War II, the organization "got their "vote and voyce" and used it "as a "bully pulpit' to further their programs"); Clarence Kolwyck, "The Ten Year Struggle for a Section of Family Law," Family Law Quarterly 3 (1969): 254 (acknowledging the role of NAWL in the creation of the Family Law Section of the ABA).

13. Roderick Phillips, Putting Asunder: A History of Divorce in Western Society (Cambridge: Cambridge University Press, 1988), 567. See also, Lawrence M. Friedman, “A Dead Language: Divorce Law and Practice before No-Fault," Virginia Law Review 86 (2000): 1497, 1511-27 (section titled "Cheating in the Shadow of the Law: The Evolution of the No-Fault Revolution").

14. Kristin Celello, Making Marriage Work: A History of Marriage and Divorce in the Twentieth Century United States (Chapel Hill, NC: University of North Carolina Press, 2009), 7; Lynne Carol Halem, Divorce Reform: Changing Legal and Social Perspectives (New York: Free Press, 1980), 229; see also, Herbie DiFonzo, Beneath the Fault Line: The Popular and Legal Culture of Divorce in Twentieth Century America (Charlottesville, VA: University Press of Virginia, 1997), 112-35, 167-70.

15. Academics who were key participants in the drafting of California's 1969 statute and the UMDA that was promulgated in 1970 by the NCCUSL have written extensively about those projects. See, for example, articles by co-reporters for UMDA, Herma Hill Kay, "An Appraisal of California's No Fault Divorce Law," California Law Review 75 (1987): 291, 299-304; and Robert J. Levy, "A Reminiscence about the Uniform Marriage and Divorce 
the no-fault changes of the 1970s were meant to be, and they disagree as to the ultimate effects of those reforms on the welfare of women and children. ${ }^{16}$ However, they have not considered what the history of NAWL's prior campaign may have to offer to our understanding of those questions. ${ }^{17}$

In the narratives about the culture of "domesticity" in the 1950s, historians have emphasized what one scholar has called the "singularity" of the American family in that decade. ${ }^{18}$ The demographic patterns of the $1950 \mathrm{~s}$ broke with those of earlier decades, at least temporarily. ${ }^{19}$ Divorce rates spiked after World War II, ${ }^{20}$ but there was a significant slowdown in the $1950 \mathrm{~s} .{ }^{21}$ At the same time, the median age at first marriage fell for both women and men. More Americans married and stayed married. ${ }^{22}$ Couples who married in the 1950 s had more children than earlier cohorts,

Act," Brigham Young University Law Review 1991 (1991): 43, 53. See also, Herma Hill Kay, "From the Second Sex to the Joint Venture: An Overview of Women's Rights and Family Law in the United States during the Twentieth Century," California Law Review 88 (2000): 2017, 2050-51. Kay also served on the Governor's Commission that drafted the first version of the California law. See Herma Hill Kay, "A Family Court: The California Proposal," California Law Review 56 (1968): 1205.

16. See, for example, Jacob, Silent Revolution, note 10 (detailing a "silent revolution" procured by technocrats working underneath the public radar); Lenore Weitzman, The Divorce Revolution: The Unexpected Social and Economic Consequences for Women and Children in America (New York: Macmillan, 1985) (arguing that California no-fault reforms had a significantly more adverse impact on the welfare of divorced women and their children than on the welfare of divorced men). But see Martha Fineman, The Illusion of Equality: The Rhetoric and Reality of Divorce Reform (Chicago: University of Chicago Press, 1991), 31-32 (criticizing the notions that no-fault was either "silent" or a "revolution").

17. See DiFonzo, Beneath the Fault Line, 5, note 14. He criticizes other historians of divorce for failing to apply insights from the California and English no-fault reforms of the late 1960s to "evaluate the evidence of earlier divorce reforms" in the mid-twentieth century. He read every popular magazine article on divorce published between the end of World War I and the 1950s. Ibid., 7. He writes about the changing status of women and divorce. Ibid., 13-36. He includes an entire chapter on "therapeutic divorce" after World War II. Ibid., 112. But nowhere does he consider the NAWL project.

18. Jessica Weiss, To Have and to Hold: Marriage, the Baby Boom, and Social Change (Chicago: University of Chicago Press, 2000), 4.

19. Ibid.

20. See Paul C. Glick, "Family Life and Full Employment," American Journal of Sociology 54 (1949): 520, 520-21.

21. See Glenda Riley, Divorce: An American Tradition (New York: Oxford University Press, 1991), 159.

22. By 1960 , only $27.4 \%$ of American women $20-24$ years old were single. The divorce rate had slowed, reaching a low point of 8.9 per 1,000 women 15 years of age and older, or 368,000 divorces, in 1958. Weiss, To Have and to Hold, 4, note 18. 
a trend that peaked in $1957 .{ }^{23}$ Some historians of popular and political culture have described what they consider to be a corresponding "domesticity" for women who were "homeward bound" in the 50s. ${ }^{24}$ Elaine Tyler May has argued that post-World War II Cold War anxieties encouraged the development of a "domestic ideology" as a "buffer." 25 With exceptions that she minimizes more than she should, May sees the family-centered generation of the 1950s as "apolitical" and leaning more to the "therapeutic approach" of experts than to social solutions for social problems. ${ }^{26}$ Family security thus acted as a kind of domestic "containment" of social and political anxiety. ${ }^{27}$ Revisionist historians such as Joanne Meyerowitz long ago began to criticize this stereotyping of American women in the 1950s. ${ }^{28}$ She warned that the domesticity narrative "flattened the history of women, reducing the multidimensional complexity of the past to a snapshot of middle-class women in suburban homes." ${ }^{29}$ In her view, it was a mistake to leave out the many who were not white, middle-class, married, and suburban, and even those among the latter who were not wholly "domestic or quiescent." ${ }^{30}$ The anthology that Meyerowitz edited in 1994 sought to displace the domestic stereotype from the center of historical study. ${ }^{31}$ It demonstrated that regardless of existing conservatism and constraints, there was a much more complicated reality operating. ${ }^{32}$

In the older narratives about activism, historians portrayed the women's rights movement as quiescent in the 1950s. Newer generations of scholars,

23. The fertility rate was 122.9 per 1,000 women compared with only 79.9 per 1,000 in 1940. Ibid.

24. Elaine Tyler May, Homeward Bound: American Families in the Cold War Era (New York: Basic Books, 1988), 1. See also Elaine Tyler May, "Pushing the Limits, 1940-1961," in No Small Courage: A History of Women in the United States, ed. Nancy Cott (New York: Oxford University Press, 2000), 492 ("The 1940s and 1950s stand out as a unique twentyyear era of domesticity").

25. May, Homeward Bound, 13, note 24.

26. Ibid., 17.

27. Ibid., 16.

28. Joanne Meyerowitz, "Introduction: Women and Gender in Postwar America, 19451960," in Not June Cleaver: Women and Gender in Postwar America, 1946-1960, ed. Joanne Meyerowitz (Philadelphia: Temple University Press, 1994), 1.

29. Ibid, 2.

30. Ibid.

31. Ibid., 5

32. Meyerowitz, "Introduction," 5-10, note 28. The contributors wrote about women's wide-ranging activism in labor unions, peace, civil rights, and civil reforms. Ibid., 6. They explored an expanded definition of feminism and found that domestic ideology was not as all-encompassing as had been said. Ibid., 7-10. They found that rather than constituting an anomalous period or representing a sharp break with pre-war activism, the 1950s served as a bridge to the greater transformations of the 1960s. Ibid., 10. 
however, criticized an account of discontinuity in which there was a first wave of activism that subsided after women gained the vote in 1920, and a second wave that did not arise until the mid-1960s. The traditional story was that in between those two waves of activism the women's movement languished in a veritable doldrums. Revisionists see a problem with the "waves" metaphor in general. ${ }^{33}$ Instead of being limited by the doldrums narrative, historians have recovered the stories of the many women who most certainly were not "quiescent" in the 1950s. ${ }^{34}$ Some revisionists take "a longer view of feminist activism," echoing an approach to the history of what has been called the "long civil rights movement." 35 Most of this revisionist work has focused on more progressive women, rather than on what historians Leila Rupp and Verta Taylor call the "elitesustained" feminist battle for the Equal Rights Amendment that was led by Alice Paul's National Woman's Party (NWP). ${ }^{36}$ Although NAWL was a white, middle-class professional organization that endorsed the ERA in

33. See, for example, Susan Hartmann, "Foreword," in Breaking the Wave: Women, their Organizations, and Femimism, 1945-1985, ed. Kathleen A. Laughlin and Jacqueline L. Castledine (New York: Routledge, 2011), xi-xii ("second wave" terminology covers up the foundations of feminism in the 1940s and 1950s "by women in traditional women's organizations, and of women of color, lesbians, religiously oriented women, radical women lawyers, and women who worked across national boundaries"); Kathleen A. Laughlin, Julie Gallagher, Dorothy Sue Cobble, Eileen Boris, Premilla Nadasen, Stephanie Gilmore, and Leandra Zarnow, "Is It Time to Jump Ship? Historians Rethink the Waves Metaphor," Feminist Formations 22 (Spring 2010): 76-135. For an early modification of the doldrums view, see Rupp and Taylor, Survival in the Doldrums, 8, note 12 (arguing that a surviving "elite-sustained" women's rights movement spanned the so-called "doldrums" of the 1950s and kept the movement alive until a broader revival in the 1960s).

34. See, for example, Kathleen A. Laughlin, "Introduction: The Long History of Feminism," in Breaking the Wave, 3-4; Susan Lynn, Progressive Women in Conservative Times: Racial Justice, Peace, and Feminism, 1954 to the 1960s (New Brunswick, NJ: Rutgers University Press, 1993), 3 (post-WWII progressive coalition "played a crucial role as a bridge that linked the prewar progressive work of women reformers with women's activism in the civil rights, antiwar, and feminist movements of the 1960s"); Dennis Deslippe, "Rights, Not Roses": Unions and the Rise of Working-Class Feminism, 194590 (Urbana, IL: University of Illinois Press, 2000) (labor union feminism); Dorothy Sue Cobble, The Other Women's Movement: Workplace Justice and Social Rights in Modern America (Princeton, NJ: Princeton University Press, 2004), 2-7 (recounting the history of a new generation of "labor feminists" who had emerged by the 1940s, whom she calls both the "other labor movement" and "other women's movement"); Landon Storrs, The Second Red Scare and the Unmaking of the New Deal Left (2013) (a study of what she calls left feminists of the New Deal who were systematically purged or silenced by the loyalty oath red scare that began in the 1940s and was formalized in 1947).

35. Susan Hartmann, "Foreword," 1, note 33 (referring to Jacqueline Dowd Hall, "The Long Civil Rights Movement and the Political Uses of the Past," Journal of American History 91 [2005]: 1233-63, at 1234).

36. See Rupp and Taylor, Survival in the Doldrums, 8, note 12. 
1935 and worked hard for it in the 1940s and 1950s, it would be a mistake to lump them with the NWP and to dismiss their uniform divorce reform project as a result. It is well worth exploring what NAWL's campaign has to add about the history of the women's rights movement in the 1950s.

Contributing to our understanding of the decade of the 1950s, this article reflects on a missing piece of the history of divorce and on an organization of professional women who were neither wholly domestic nor quiescent in their pursuit of their "greatest project."

\section{Origins and History of the NAWL}

The origins of the NAWL can be traced to a New York women lawyers' club that started meeting in 1899 and was the largest of similar groups in other cities. ${ }^{37}$ In her article on the "new woman lawyer" of the early twentieth century, Virginia Drachman explained that these clubs were part of a double development: They reflected "the general trend of organization which permeated the entire legal profession" at a time of professionalization and the spread of local and state bar associations. ${ }^{38}$ At the same time, many of those organizations were not open to women. They therefore founded their own bar associations as a way to combat sex discrimination and also to express their professional identification. ${ }^{39}$

In 1911 the New York club undertook a national project, the Women Lawyers Journal, a publication that continues today. ${ }^{40}$ Drachman noted that the existence of the Journal immediately boosted membership in the association, from 20 in 1911 to 76 within 2 years, to 130 by 1914, and that it spread representation beyond the local region. ${ }^{41}$ The Journal "had a special mission; namely, to meet the unique professional needs of women lawyers." 42 This encompassed professional and practical matters and created a vehicle to monitor legal reforms that interested women

37. Joyce, "How We Started," 13, note 2.

38. Drachman, "The New Woman Lawyer," 245, note 1.

39. Ibid. The New York club was a good example. Women were excluded from the general bar. The women's bar "provided women lawyers with the unique opportunity to come together for social as well as professional interaction." Ibid., 246. The women lawyer's club affiliated itself to the women's movement by joining the General Federation of Women's Clubs in 1900. Ibid. Women who were excluded from the District of Columbia Bar formed a female association in 1917 that had close ties to suffrage leaders at the cusp of the success of that movement. Ibid.

40. See Women Lawyers Journal 1 (1911-12): 1; and Joyce, "How We Started," 13, note 1 .

41. Drachman, "The New Woman Lawyer," 246, note 1.

42. Ibid. 
lawyers. The Journal also was a place to announce professional achievements. ${ }^{43}$ It "helped to build a national network of women lawyers." 44 Even though the ABA opened its membership to women in 1917 (although the same was not necessarily true of local bar groups), the female membership of the organization that was renamed the National Association of Women Lawyers still felt the need for a separate entity in addition to the ABA. ${ }^{45}$ This posed the ongoing and contested question of whether there was something unique about women's place within the profession. ${ }^{46}$ In the 1930s it was clear that even in sex-integrated bars or in government positions, women rarely enjoyed the same opportunities as men. ${ }^{47}$

The women of NAWL later claimed that "the JOURNAL started a crusade of publicity for women in the law or otherwise in the public eye, as in suffrage, business, or politics." 48 In 1911, the editors of the first issue explained that although NAWL was an organization of lawyers, the Journal was devoted to the interests of "all womankind"; that is, "whatever touched women particularly." 49 That viewpoint, however, did not mean that it was not interested in how "woman's cause" touched "man's cause" and all humanity. ${ }^{50}$ The Journal's editors avowed that they did not want to assume an "antagonistic feministic view." 51 Whatever label NAWL's Journal eschewed, however, from its origins it was explicitly dedicated to women's rights. The initial volume included articles and notes on education and advancement for women lawyers, the women's club movement, suffrage, politics, industrial protection, temperance, uniform divorce reform, and conflicts of law in divorce jurisdiction. ${ }^{52}$ The concerns reflected in the Journal placed NAWL squarely within the Progressive reform currents of the day at a time that some historians describe as an apogee of women's participation in public life: in voluntary organizations, lobbying, trade unions, professional education, and professional activity. ${ }^{53}$ The Journal published allied items on Progressive causes

43. Ibid.

44. Ibid.

45. Ibid.

46. Ibid., 247.

47. Ibid., $248-50$.

48. Joyce, "How We Started," 13, note 2; see also Selma Moidel Smith, "A Century of Achievement: The First 50 Years," Experience 9 (1998-99): 6-12.

49. "Our Aim," Women Lawyers Journal 1 (1911-12): 1.

50. Ibid.

51. Ibid.

52. Women Lawyers Journal 1 (1911-12): 1- 8 passim.

53. See, for example, Sara M. Evans, Born for Liberty: A History of Women in America (New York: Simon \& Schuster, 1989, 1997), 160 ("women's movement reached the apex of its political power" between 1900 and World War I, achieving new laws for pure food, 
such as the women's club movement, ${ }^{54}$ temperance, ${ }^{55}$ and other reforms that it regarded as protecting women and children, such as the creation of "widows" or "mothers" pensions. ${ }^{56}$ Like other Progressive organizations, NAWL approved social feminist efforts to pass and defend genderspecific protective labor laws for women, although it abandoned this position after it endorsed the ERA in $1935 .{ }^{57}$ Equally consistent with reform preoccupations of the day, NAWL's Journal also reported favorably on efforts to control marriage of the "unfit" (eugenics). ${ }^{58}$ The implicit and sometimes explicit racism of white Progressive reform movements also was reflected in its columns. ${ }^{59}$

In particular, however, the Journal was a women's rights vehicle. It aimed to encourage the professional advancement of women lawyers, judges, and public servants and to combat discrimination against them. ${ }^{60}$ It published news and articles about women's suffrage, ${ }^{61}$ discrimination

protective legislation regulating wages and hours for working women and children, prison and court reforms, and the creation in 1912 of a Federal Children's Bureau headed by former Hull House resident Julia Lathrop). For examples of Progressive era women's activism, see also ibid., 139-40 (describing the wave of association building characterized by the formation of women's clubs focused on specific themes and attracting a broad audience), 151-52 (describing black professional and other middle-class women who organized their own clubs and settlement houses, which focused on issues important to their own communities, such as the campaign against lynching), and 148-50 (describing the growth of the settlement house movement and alliance with the women's club movement).

54. See, for example, "Mrs. Philip (Fannie H.) Carpenter, Our Choice for President of the General Federation of Womens' Clubs," Women Lawyers Journal 2 (1912): 33.

55. See, for example, "New York Liquor Laws," Women Lawyers Journal 1 (1911): 4.

56. See, for example, "Widows' Pensions: Theory and Practice," Women Lawyers Journal 3 (1914): 33.

57. See, for example, Jean H. Norris, "Women are Compelled to Fight for Rights under 8-Hour Law," Women Lawyers Journal 3 (1914): 28; The Rev. Edwin V. O'Hara, “Minimum Wage Legislation," Women Lawyers Journal 4 (1915): 49.

58. See, for example, Harriette M. Johnston-Wood, "Need for Legislation to Refrain the Unfit from Procreating," Women Lawyers Journal 2 (1912): 41, 47.

59. "Woman Lawyer Follows Up Case," Women Lawyers Journal 3 (1914): 25, 29 (story about a little white child who was locked in jail with two Negro women because of her mother's consorting with a "Negro paramour" from which she was rescued by a "humane" woman lawyer.) See also, William O'Neill, Everyone Was Brave: A History of Feminism in America (New York: Quadrangle-New York Times Books Co., 1976), 70 ("[A] 'pact between woman suffrage and white supremacy' [was] both natural and expedient").

60. See "Our Aim," 1, note 49 (stating that "our aim" was to further the cause of women lawyers and of all womankind). See, for example, "Women in Office," Women Lawyers Journal 1 (1911): 17; "Women Appointed Commissioners," Women Lawyers Journal 1 (1911): 8; "Judge Hopkins on Women Lawyers," Women Lawyers Journal 1 (1911): 19.

61. See, for example, Women Lawyers Journal 1 (1911-12): 17-24, passim; and the "Suffrage Issue," Women Lawyers Journal 5 (1915-16): 1-8. 
against "mother-teachers,"62 the loss of citizenship for American women who married foreign husbands, ${ }^{63}$ and civil service discrimination against women. ${ }^{64}$ Even after suffrage was obtained, NAWL continued to pursue its women's rights agenda. ${ }^{65}$ In 1932 it was one of the primary women's organizations that filed amicus petitions in an unsuccessful effort to persuade the Supreme Court to review a Massachusetts law that excluded women from jury service. ${ }^{66}$

\section{NAWL and Migratory Divorce}

From the outset, the Women Lawyers Journal reflected the women lawyers' special interest in divorce law. ${ }^{67}$ The first issue in 1911 included two articles about the conflicts arising from migratory divorces; that is, those involving unhappy spouses who could not satisfy rigid rules at home, and therefore repaired to more liberal states in order to obtain a divorce. ${ }^{68}$ The first was a report on a contemporary effort by conservatives who sought to rein in this phenomenon through strict uniform divorce legislation. ${ }^{69}$ Historically, anxieties about rising divorce rates had been linked to concerns about migratory divorce and from time to time had led to demands for restrictive measures. ${ }^{70}$ According to historian William

62. See, for example, "The Mother-Teacher-Who Knows Her Rights?" Women Lawyers Journal 2 (1912): 73, 75.

63. See, for example, Katherine Horan, "The Citizenship of Women as Affected by Marriage," Women Lawyers Journal 3 (1914): 25.

64. See, for example, "Women Fight Discrimination in Civil Service Appointments," Women Lawyers Journal 2 (1912): 73, 74.

65. See, for example, Florence Thacker, "The Married Woman Worker," Women Lawyers Journal 19 (Winter 1932): 32; and Gail Laughlin, "Discrimination Against Women Workers," Women Lawyers Journal 22 (1935-36): 18.

66. See "Motion of National Association of Women Lawyers for Leave to File Brief as Amicus Curiae," note 4.

67. Some of the earliest opportunities open to women lawyers and as judges in the 1910s and 1920s were in family-related fields such as the juvenile courts established first in Chicago in 1899, and the all-female "women's courts" established in Los Angeles and some other locales. These separate courts were short lived. See Drachman, "The New Woman Lawyer," 241, note 1.

68. "Uniform Divorce Legislation," Women Lawyers Journal 1 (1911): 5; and Minnie Neugass, "The Conflict of Laws in Divorce Actions," Women Lawyers Journal 1 (191112): 5,6 .

69. "Uniform Divorce Legislation," 5, note 68.

70. See, for example, Riley, Divorce: An American Tradition, 62-67, 110-11, note 21 (discussing the development of divorce havens after 1850 and the reactions against them and the work of the New England Divorce Reform League and Samuel W. Dike); see also Henrik Hartog, Man and Wife in America: A History (Cambridge, MA: Harvard 
O'Neill, the antidivorce cycle of the early twentieth century occurred in "crucial years for divorce" that were the "last time when public opinion could reasonably have been expected to support genuinely repressive action" against rising divorces rates." 71 Conservatives sought uniform laws that would limit divorce throughout the nation. ${ }^{72}$

In 1906, President Theodore Roosevelt agreed to convene a nongovernmental National Congress on Uniform Divorce Laws to draft measures to control divorce. ${ }^{73}$ Some "women's rights leaders" were "alarmed" by the conference call. ${ }^{74}$ They feared the likelihood that men would once again be determining matters of great importance for women's lives. ${ }^{75}$ Once the conference met, however, the delegates to the National Congress who represented different states and religious interests found it hard to agree on any substantive principles. ${ }^{76}$ They were able to approve only a modest model statute designed to limit migratory divorce. ${ }^{77}$ The draft law was adopted by the NCCUSL in 1907. NCCUSL's Uniform Act, however, gained no traction in the states and the commissioners withdrew their approval in $1928 .^{78}$ At the peak of the antidivorce crusade in 1906, the

University Press, 2000), 264; and Norma Basch, "The Emerging Legal History of Women in the United States: Property, Divorce, and the Constitution," Signs 12 (1986): 97, 108.

71. William L. O'Neill, Divorce in the Progressive Era (New Haven, CT: Yale University Press, 1967), 254-55. See also William L. O'Neill, "Divorce in the Progressive Era," American Quarterly 17 (1965): 203, 206.

72. Phillips, Putting Asunder, 471, note 13.

73. Riley, Divorce: An American Tradition, 115, note 21.

74. Ibid., 115.

75. Ibid., 116. Elizabeth Cady Stanton decried the control of men over marriage and divorce laws. Alice Park, Secretary of the California Equal Suffrage Association asked the governors to appoint otherwise disfranchised women to the convention in light of the importance to them of the subject. Ibid. The results of the conference brought mixed responses from feminists: Elizabeth Cady Stanton was glad that it had failed to cut off the escape valve from oppressive marriages, but other feminist figures had hoped for some measure of uniform law. Ibid., 118. Others thought that the cause of suffrage should be kept separate and apart from any other issue. Ibid.

76. Ibid., 117. Representatives from the disparate states disagreed passionately on how restrictive to make the grounds for divorce. Ibid.

77. The antimigratory proposal provided that if an inhabitant of one state went to another state to obtain a divorce on a ground that was not recognized in his or her own state, the divorce would have no legal effect at home. Phillips, Putting Asunder, 469-70, note 13. It also would have imposed a minimum 2 year residency requirement in order to file for divorce. Nelson Blake, The Road to Reno (New York: Macmillan, 1962), 141. On the Congress, see also Riley, Divorce: An American Tradition, 115-18, note 21.

78. See Ann Laquer Estin, "Family Law Federalism: Divorce and the Constitution," William \& Mary Bill of Rights Journal 16 (2007): 381, 391; Blake, The Road to Reno, 145 , note 77 . Only three states (New Jersey, Delaware, and Wisconsin) endorsed or adopted the model uniform statute. Ibid. 
Supreme Court also chimed in with a limiting decision. In Haddock v. Haddock, the Supreme Court held that jurisdiction to enter an original divorce decree entitled to recognition in sister states depended on which spouse was at "fault" for disrupting the marital domicile. ${ }^{79}$ It did not overrule this ruling until 1942.80

In the second article in the 1911 issue of the Women's Lawyers Journal, Minnie Neugass provided a practical recipe for the steps needed to obtain an out-of-state divorce that would be valid everywhere. ${ }^{81}$ She explained that under existing constitutional law this could only be done if the spouses were both personally within the jurisdiction of the court where the divorce suit was filed or if at least one of the parties was genuinely domiciled in that state. ${ }^{82}$ Neugass noted that in general a husband unilaterally established the domicile for his wife. ${ }^{83}$ But if the husband was at fault in the breakup of the marriage, the innocent wife could and must establish her own separate domicile. ${ }^{84}$ Therefore, proper jurisdiction depended on "fault." An absconding guilty husband could not force an innocent wife to answer to a suit in his new domicile, but a guilty wife could be sued there. ${ }^{85} \mathrm{~A}$ wife who left the marital jurisdiction could still sue her husband where he was domiciled; the stay-at-home wife could sue her spouse either in the state of the former marital domicile or in the state "to which he removes." $" 86$ In light of this jurisdictional law, Neugass emphasized that one "seeking release from the bonds of matrimony" needed to obtain a decree that was valid everywhere. Otherwise, the person could be divorced in one place but still married and subject to prosecution for bigamy upon remarrying in another. ${ }^{87}$

Articles appearing in the Journal in the 1930s implied that NAWL members were open to more liberal divorce laws, at least in the most stringent states. ${ }^{88}$ In a talk delivered in Reno and reported in the Journal in 1932,

79. Haddock v. Haddock, 201 U.S. 562 (1906). Marital domicile was a principle derived from the common law and its patriarchal model of marital unity, as reflected in Barber v. Barber, 62 U.S. 582 (1858). Barber established that the general rule of the husband's authority to establish the domicile for both parties prevailed unless the husband was guilty of wrongfully abandoning his wife. Haddock v. Haddock, 201 U.S. at 571 (quoting Barber v. Barber).

80. Williams v. North Carolina, 317 U.S. 287 (1942).

81. Neugass, "The Conflict of Laws in Divorce Actions," 6, note 68.

82. Ibid.

83. Ibid.

84. Ibid.

85. Ibid.

86. Ibid.

87. Ibid.

88. See, for example, Josephine S. Valentine, "Incompatibility as a Ground for Divorce," Women Lawyers Journal 2 (1912): 49, 53-54; "New Jersey Divorce Law," Women Lawyers 
Felice Cohn of Nevada even defended the generous migratory divorce laws of her home. ${ }^{89}$ She noted that her state frequently was "criticized, censure [d], and even reviled for our liberal laws, but have you ever stopped to consider that that is what the people desire, or they would not be enacted." 90 Reno itself should not be held up to scorn, she said, because "it is due almost entirely to the need of relief from irksome bonds of matrimony of the citizens of other states that we find ourself [sic] the 'Cure' center of the World." 91 Cohn claimed that Nevada courts were careful to protect deserving wives and minor children and to provide all parties a fair hearing. ${ }^{92}$ Finally, she minimized the uncertainties surrounding the recognition of Nevada decrees in other states. In fact, she argued, there were only four states that questioned their validity-New York, New Jersey, Pennsylvania, and Connecticut - and even then it did not come up very often. ${ }^{93}$ Cohn defended the "fairer and more humane" law of Nevada, which refused to keep an unhappy couple yoked together forever just because both of them were partially at fault in their marital breakdown. ${ }^{94}$

In 1935 NAWL held a comprehensive Forum on Divorce Problems at its Annual Convention. ${ }^{95}$ The reporter, Martha Gold, was a sponsor of divorce reform in the District of Columbia. ${ }^{96}$ She summarized the great disparities in divorce law grounds in the various American jurisdictions. ${ }^{97}$ Residency rules also varied widely, thereby creating likely centers for migratory divorce. Forty-seven states and the District of Columbia granted divorces for adultery; South Carolina banned absolute divorce in its constitution (although it allowed a legal separation that permitted support orders but did not allow remarriage) ${ }^{98}$ forty-six states permitted desertion or abandonment grounds; forty-two permitted cruelty; thirty-eight permitted drunkenness or addiction to drugs; and forty-two permitted imprisonment for a felony. ${ }^{99}$ The disparities between the states extended to migratory

Journal 2 (1912-13): 73, 78; N. Ruth Wood, "Marriage and Divorce Laws," Women Lawyers Journal 33 (1947): 23, 27; and "Chronological History of Uniform Marriage and Divorce Law Movement," Women Lawyers Journal 33 (1947): 30-31.

89. Felice Cohn, "Nevada Divorce Law," Women Lawyers Journal 12 (1922-23): 16.

90. Ibid., 16.

91. Ibid.

92. Ibid., 17.

93. Ibid.

94. Ibid., 16-17.

95. Martha R. Gold, "The Divorce Situation in the Various States," Women Lawyers Journal 22 (1935-36): 5.

96. Ibid.

97. Ibid.

98. Ibid.

99. Ibid. 
divorce. Nevada had the lowest barrier to filing a petition, with a residency of only 6 weeks; Connecticut ( 3 years) and Massachusetts ( 5 years) had the highest. In light of these differences, it was not surprising that Nevada and Florida became magnets for migratory divorces or that unhappy spouses who fled New York, Massachusetts, and Connecticut later became litigants in the Supreme Court's divorce jurisdiction cases. ${ }^{100}$ In the 1930s, NAWL writers already were bemoaning the patchwork of archaic state divorce laws that encouraged migratory divorce.

\section{Divorce in the Mid-Twentieth Century and NAWL's "Greatest Project"}

By the time NAWL launched its project in 1947, the incidence and culture of divorce in America had been transformed, but the law was relatively frozen in place. After World War I and in the interwar years, the rate of American divorces began a long-term secular rise toward an age of "mass divorce."101 Although the economic crisis of the Great Depression of the 1930s flattened the upward-tending curve, that was only a temporary check. ${ }^{102}$ Interested states still competed for the migratory divorce trade. ${ }^{103}$ Nevada, Idaho, and Arkansas engaged in a "veritable trade war ... each vying for out-of-state clients for its divorce courts." 104 In 1931, Nevada reduced its already low 3 month residency requirement still further, to 6 weeks, "“in a frenzied attempt to head off threatened rivalry" from other states. ${ }^{105}$ Despite the excited media attention, however, migratory divorces comprised only a "negligible fraction" of marital dissolutions. ${ }^{106}$

Marriage and divorce rates climbed once again in the wake of World War II and the concurrent revival of the United States economy. ${ }^{107}$

100. For example, Sherrer v. Sherrer, 334 U.S. 343 (1948) (migratory divorce from strict Massachusetts to permissive Florida); Coe v. Coe, 334 U.S. 378 (1948) (migratory divorce from strict Massachusetts to permissive Nevada); and Estin v. Estin, 334 U.S. 541 (1948) (migratory divorce from strict New York to permissive Nevada).

101. Phillips, Putting Asunder, 561, note 13.

102. Ibid., 555. See also James Wetzel, "American Families, Seventy-Five Years of Change," Monthly Labor Review 4 (March 1990): 6-9 (fewer people married and fewer people divorced in the 1930s).

103. Phillips, Putting Asunder, 533, note 13.

104. Ibid., 531.

105. Friedman, "A Dead Language," 1504, note 13.

106. Herbie DiFonzo, "Alternatives to Marital Fault: Legislative and Judicial Experiments in Cultural Change," Idaho Law Review 34 (1997): 1, 27-28.

107. Wetzel, "American Families," 6-9, note 102. See also Phillips, Putting Asunder, 555 , note 13 . 
Americans began to create new families in record numbers during the war. ${ }^{108}$ There were more than $1,000,000$ families formed between 1940 and 1943 than in comparable preceding years, and fertility increased when the United States entered the war. ${ }^{109}$ Those hikes extended to divorce, too. Paul Glick of the Bureau of the Census reported in 1949 that based on previously projected long-term trends three million more marriages but also one million extra divorces than expected had occurred between 1940 and 1947. ${ }^{110}$ When the veterans came home in 1946, divorces spiked to twice the usual number. ${ }^{111}$ The increases then plateaued for the $1950 \mathrm{~s}$. The divorce rate ranged between $2.1 \%$ and $2.5 \%$ annually, a level not dramatically higher than the rates of $1.8 \%$ and $1.9 \%$ in the late 1930s. The relative slowdown, however, proved to be merely a temporary lull before the storm. More Americans than ever before divorced in the 1960s. Divorce rates skyrocketed in the 1970s before peaking in the early 1980 s and then remaining more stable at a relatively high level. ${ }^{112}$ Therefore, because NAWL began its project in 1947 and then pursued it doggedly throughout the 1950 s, there is no exact correspondence between their campaign and rising divorce rates.

It is difficult to isolate all the reasons that induced a growing number of Americans to divorce. ${ }^{113}$ Historians seem to agree, however, that the rises were not driven by any change in formal law. ${ }^{114}$ Rather, the law followed rather than led the social changes that made divorce a more acceptable resolution to marital breakdowns. Couples seeking divorce in the 1930s through 1950s often were able to evade the strictures of rigid fault-based

108. May, Homeward Bound, 59, note 24.

109. Ibid.

110. Glick, "Family Life and Full Employment," 520-21, note 20.

111. See Celello, Making Marriage Work, 4, note 14, for a table of divorce rate trends, 1900-2000; May, Homeward Bound, 7 (Table 5, Annual Divorce Rate per 1000 Married Women, 1860-2004), note 24.

112. Weiss, To Have and to Hold, 178, note 18; see also Phillips, Putting Asunder, 567, 582,619 , (The annual changes in the divorce rate showed a decline from 1947 to 1958 , a steady increase of between $4 \%$ and $5 \%$ annually from 1959 , and increases of between $9 \%$ and $12 \%$ a year from 1968 to 1972 . After 1973, the rate of increase slowed, but the divorce rate still climbed, and only stabilized after 1982.) Note 12.

113. See, for example, Riley, Divorce: An American Tradition, 144-55. (Contemporary "experts" in the first half of the twentieth century cited factors such as American individualism, rising expectations of marriage, increased median income, industrialization, decline in economic functions of the family, weakening of religious tenets, fading social stigma concerning divorce, and changes in women's roles.). Note 21.

114. DiFonzo, Beneath the Fault Line, 1-3, note 14. 
statutes. ${ }^{115}$ Trial courts commonly tolerated unspoken collusion by the divorcing spouses. ${ }^{116}$ To a lesser extent, unhappy wives and husbands also migrated to more liberal jurisdictions to get divorced. ${ }^{117}$ Regardless of legal doctrines that prohibited the practice, the collusive and migratory dissolutions constituted what the consumers wanted; that is, divorce by mutual consent. ${ }^{118}$ As a result, the law on the books was growing ever more out of sync with the practice of law as well as with popular expectations about marriage and divorce. ${ }^{119}$

Although it is hard to find reliable data, by midcentury there were thousands of women practicing law in the United States and many, if not most of them likely were practicing divorce law. ${ }^{120}$ The women lawyers of NAWL had been interested in divorce law reform since 1911. In 1947, they undertook their most ambitious project ever: they announced that they intended to draft a uniform no-fault divorce law designed to align the formal law with modern mores as well as to redress the problem of migratory divorce abuse. ${ }^{121}$ During the war, the organization had gained some acknowledgment from the ABA that may have helped to shape their ambitions for the project. ${ }^{122}$ NAWL aimed to produce a model law that would be promulgated under the auspices of the NCCUSL and adopted by each state individually. It chose that tactic to achieve uniformity because the American system of federalism rendered direct federal

115. See, for example, J. Herbie DiFonzo and Ruth C. Stern, "Addicted to Fault: Why Divorce Reform Has Lagged in New York," Pace Law Review 27 (2007): 557, 559 (describing New York's unchanged strict grounds and how couples evaded them).

116. Riley, Divorce: An American Tradition, 143-44, note 21.

117. Halem, Divorce Reform, supra note 14, at 234.

118. DiFonzo, Beneath the Fault Line, 9, note 14.

119. Ibid., 1-2. See also Friedman, "A Dead Language," note 13 (discussing divorce practice in the 1930s and 1940s).

120. Some data indicated that in 1940 there were only 39 African-American women lawyers in the United States, 4,146 white women lawyers, and 172,329 white male lawyers. Drachman, 234, note 1. After the war, the American Bar Association undertook a massive Survey of the Legal Profession. Martindale-Hubbell's Law Directory listed 169,489 lawyers in the United States in 1948. The report estimated there were 2997 women lawyers, a number that because of the shortcomings of the survey method was clearly an undercount. "2997 Women Lawyers," Women Lawyers Journal 36 (1950): 16. See also Albert P. Blaustein and Howard S. Kaplan, "America's Women Lawyers and the 1949 Lawyer-Count," Women Lawyers Journal 37 (1951): 18; and Dorothea Blender, "The President Reports," Women Lawyers Journal 39 (1953): 7 (asserting that the figure was "obviously" "far short" and that there were more likely 12,000 women lawyers).

121. Wood, "Marriage and Divorce Laws," 27-29, note 88.

122. The ABA finally permitted NAWL to become one of its auxiliary legal organizations in 1943. Raggio, "Women Lawyers in Family Law," 503, note 12. 
legislation on marriage and divorce unconstitutional. ${ }^{123}$ The abortive effort by the General Federation of Women's Clubs and Senator Arthur Capper of Kansas to amend the United States Constitution in order to overcome this difficulty lasted from 1922 to 1947, when Senator Capper ceased introducing his bills. ${ }^{124}$ NAWL studied the Capper amendment and also a proposed Full Faith and Credit statute proposed by Senator Patrick McCarran before adopting its solution. "They felt that a clear, simple model of a uniform divorce bill had never been drafted and presented to the states for adoption and so this proposed solution had never been given a fair trial." 125

NAWL believed that widespread state-by-state enactments of a model act could bring about the desired uniformity. Along these lines, it also enthusiastically supported the Uniform Reciprocal Enforcement of Support Act (URESA). ${ }^{126}$ That statute dealt with the increasing numbers of ex parte divorces in which a deserting husband left his home state jurisdiction to evade responsibility for support of his family. Promulgated by NCCUSL in 1950 and quickly approved by the ABA, URESA was the most successful uniform act to date. By 1954, thirty-seven states had adopted the provision, which had the effect of protecting the public purse from the necessity of supporting dependent and abandoned wives and families of husbands who had fled the jurisdiction. ${ }^{127}$ However,

123. Its conclusion that federal law on marriage and divorce would be unconstitutional led the antidivorce National Congress on Uniform Divorce Laws of 1906 to propose the model law on migratory divorce that the uniform commissioners adopted in 1907 (and later withdrew). Phillips, Putting Asunder, 469, note 13.

124. The proposed amendment stated: "the Congress shall have the power to make laws, which shall be uniform throughout the United States, on marriage and divorce, the legitimation of children, and the care and custody of children affected by divorce." Blake, The Road to Reno, 149, note 77. There was support for the Capper Amendment from the National Congress of Parent Teachers, the National Federation of Business and Professional Women, the Woman's Christian Temperance Union, and the Daughters of the American Revolution. Ibid. But there also was significant conservative opposition. Ibid. Numerous women's groups favored national regulation because they hoped it would offer protection to women and children left unsupported in the event of migratory divorces. But conservative religious groups opposed the amendment because they feared that the result would be to liberalize the divorce laws of strict states. White supremacists also opposed the amendment for fear that it would lead to the approval of interracial marriages. With all the interests opposed, the amendment had no chance of enactment by Congress. Caldwell, "Not Ozzie and Harriet," 39, note 12.

125. Matilda Fenberg, "The Uniform Divorce Bill: A Proposed Solution for Our Divorce Muddle," American Bar Association Journal 41 (1955): 247.

126. "Editor's Note," Women Lawyers Journal 37 (1951): 21. (“There has probably been no bill in recent years excluding the NAWL endorsed Uniform Divorce Bill, which our members have as a whole so heartily approved as this Bill.")

127. Caldwell, "Not Ozzie and Harriet," 45, note 12. 
husbands who managed to obtain an ex parte migratory divorce still could evade the effect of this legislation. ${ }^{128}$

From the inception of its project, NAWL avowed that it was repudiating the fault basis for divorce in favor of a more modern approach. In a "classic article"129 in 1947, N. Ruth Wood, then Chair of NAWL's Committee on Marriage and Divorce Law, explained the newer view: people now "generally believe that the unwanted marriage relationship should be broken."130 Unfortunately, however, the lingering effects of the history of divorce law meant that outmoded statutes continued to require that one party "must be innocent and wronged and the other guilty of some specific act prescribed by statute which renders the innocent spouse entitled to a divorce."131 "This theory is contrary to our present mores," she continued, "as common thought today is that divorce is a remedy for domestic incompatibility and should be granted when the parties consent." 132 Although the current laws precluded consensual divorce in theory, Wood noted that in practice collusion occurred all the time. Furthermore, there were all kinds of conflicting state laws, from the hyper-strictness of South Carolina (no divorce) and New York (only adultery) to the liberal divorce mills. In a highly mobile population, these disparities led to inconsistency and confusion. ${ }^{133}$

Wood argued that it was time for reformed divorce laws based on a more "conciliatory" philosophy. ${ }^{134}$ In this "age of the common man," she wrote, Social Security laws "have been enacted "to defend all families against any common economic risk that threatens their independence and wellbeing." "135 Similarly, family law should recognize marital risk. To succeed, marriages had to be based on "the satisfaction of the individuals."136 When they failed to do so, Wood explained, then divorce should be available not as a punishment, but as a common sense solution for a sad situation. ${ }^{137}$

Although NAWL acted first, it was not alone in its critique of the increasingly out-of-sync state of the law. ${ }^{138}$ In 1948, President Harry

128. Ibid., 46.

129. Kolwyck, "The Ten Year Struggle," 255, note 12.

130. Wood, "Marriage and Divorce Laws," 27-29, note 88.

131. Ibid., 27.

132. Ibid.

133. Ibid.

134. Ibid., 29.

135. Ibid.

136. Ibid.

137. Ibid., 28.

138. NAWL's leadership has escaped the notice of prominent historians such as J. Herbie DiFonzo. See, DiFonzo, Beneath the Fault Line, 125 (discussing the ABA's Report to the 
Truman convened a National Conference on Family Life. Much had changed in American culture since 1906, when Theodore Roosevelt had called together the militantly antidivorce National Congress on Uniform Divorce Laws, although each gathering occurred following a great war and sounded a family-saving theme. One hundred twenty-five agencies and experts interested in the welfare of the family met under private auspices in 1948. ${ }^{139}$ The goal of the conference "was to discover specific means by which the American family may be strengthened for the benefit of its individual members and society." 140 An Inter-Agency Committee on Background Materials provided government data. ${ }^{141}$ The volume included a chapter on the "Legal Status of the Family" that had been prepared by the Women's Bureau in the Department of Labor in collaboration with the Children's Bureau and the Bureau of Public Assistance of the Federal Security Agency and the Bureau of Labor Standards in the Department of Labor. ${ }^{142}$ Although the data provided were presented objectively, the Women's Bureau was a center of the "Women's Bureau Network," a loose coalition of progressive labor and women's organizations who, unlike NAWL, actively opposed the ERA at this time. ${ }^{143}$

Although the background volume described some limited new trends in the traditional law of husband and wife, two thirds of the states still treated property acquired during the marriage as being under the control of the husband as the "head of the family." 144 Divorce law was even more hidebound than the law of marriage. According to the legal status chapter there were six main types of divorce grounds recognized in the various states: "conduct violating the sanctity of the marriage relation; violent or gross conduct, menacing life, health, or happiness; conduct showing willful or negligent disregard of marital obligations; incapacity to fulfill marital obligations; civil death through criminal status or prolonged absence without

Family Life Conference in May of 1948 without mentioning that NAWL had already begun its project), note 14 .

139. Paul W. Alexander, "Family Life Conference Suggest New Judicial Procedures and Attitudes toward Marriage and Divorce," Journal of the American Judicature Society 32 (1948): 38.

140. Inter-Agency Committee on Background Materials for the National Conference on Family Life, The American Family: A Factual Background (Washington, DC: InterAgency Committee on Background Materials, 1948), ii.

141. Ibid., i.

142. Ibid., 341.

143. The network included most activist women's organizations except for those that were primarily focused on the ERA, such as Alice Paul's NWP. Cobble, The Other Women's Movement, 50-51, note 34. Labor women became the "dominant constituency" of this coalition after the 1930s. Ibid., 105.

144. Ibid., 349. 
word of whereabouts; or defective marriage."145 Twenty-four states granted only "absolute" divorces; that is, decrees that severed the marriage relation completely and allowed remarriage. ${ }^{146}$ Twenty-three states and the District of Columbia provided either for absolute or for "limited" divorce (a legal separation that permitted support orders but did not allow remarriage). ${ }^{147}$ South Carolina did not grant absolute divorce on any ground, but permitted wives to gain legal separation in some instances. ${ }^{148}$

During early planning for the Family Life Conference, the Governing Board of the ABA was approached to send a legal delegation. At first reluctant to do so, the board only changed its mind and acceded to the importuning of Reginald Heber Smith (of Legal Aid fame), William L. Ransom, and Olive G. Ricker when it learned that otherwise the left-leaning National Lawyers Guild would become the sole delegation representing the legal profession. ${ }^{149}$ The president of the ABA then appointed Smith to chair a liaison committee that included Clarence Kolwyck of the Chattanooga Bar (who had revealed "divorce mill" abuses in his city), William P. MacCracken, Jr., of Washington (former secretary of the ABA), Charlotte E. Gauer of Chicago (president of NAWL), William L. Ransom of New York (former ABA president), and Judge Paul W. Alexander of Toledo Ohio (well-known for presiding over that city's Juvenile Court). ${ }^{150}$

When Smith published an early draft of the ABA delegation's proposed report in the December 1947 issue of the Atlantic Monthly, he reported receiving telling responses. ${ }^{151}$ Lawyers were disgusted and ashamed of the role that they played in a divorce drama that required them to engage in "double-talk" in advising their clients, judges were "bitter" about their "impotence," social workers expressed "unconcealed scorn," and the

145. Ibid., 368. There were some grounds exclusively reserved for husbands, "mostly the wife's pregnancy by another man undisclosed at the time of marriage," and some for wives, "usually the husband's desertion or nonsupport." Ibid.

146. Ibid.

147. Ibid.

148. Ibid.

149. Kolwyck, "The Ten Year Struggle," 254, note 12. For the resolution approving the delegation, see "Report of the Delegation of the American Bar Association to the National Conference on Family Life," Annual Report of the American Bar Association 73 (1948): 302,303 .

150. "Divorce Laws: Remedies for Abuses and Scandals Are Sought," American Bar Association Journal 34 (1948): 195. See also Kolwyck, "The Ten Year Struggle," 254, note 12. Clarence Kolwyck himself was "unwittingly catapulted into the family law movement" after his investigation of a Chattanooga "divorce mill ... which rivaled Reno and Mexico" attracted national attention. Ibid., 255.

151. "Divorce Laws: Remedies for Abuses and Scandals Are Sought," 196, note 150. 
press and periodicals showed their "contempt" for divorce laws, including decisions of the Supreme Court. ${ }^{152}$ Smith concluded that American divorce laws were a "mess" and that "society, by and large, has practically made up its mind to ignore the law." 153

In an initial report to the executives of the Family Life Conference in March of 1948, ${ }^{154}$ Smith explained that the old premise of guilt and punishment should be replaced with that of "prevention." 155 The punishment model yielded only abuse and injustice. It forced "normally decent people" to commit perjury or adultery." 156 The new premise of prevention, on the other hand, might or might not accomplish very much but anything it did would be "pure gain" because at least the lying, cheating, and unfaithfulness would be avoided. ${ }^{157}$ Instead of legalistic sleight-of-hand, "applied social case-work" drawing on all the resources of the community could be brought to bear. ${ }^{158}$ "American Public Opinion," Smith avowed, "is Ready for a Revolutionary Change." 159

Judge Paul W. Alexander of Toledo's Juvenile Court subsequently succeeded Smith as Chair of the ABA delegation. ${ }^{160} \mathrm{He}$ was one of the chief proponents of what historian J. Herbie DiFonzo has called "coercive conciliation" through the administration of divorce law through family courts based on the juvenile court model. ${ }^{161}$ The final report of the delegation explained that as a dissolving family was already broken before divorce, rather than by that legal remedy, it was necessary to change from a focus on punishment to one based on treatment. ${ }^{162}$ Following the juvenile court prototype, courts (preferably integrated family courts) should become conduits through which expert specialists could offer conciliation services. ${ }^{163}$ The delegation's final report also introduced a dose of realism to balance a desire for family preservation. It acknowledged that feuding

152. Ibid., 195.

153. Ibid., 196.

154. Ibid., 195.

155. Ibid., 196. See also Alexander, "Family Life Conference," note 139 for a more complete version of final report.

156. "Divorce Laws: Remedies for Abuses and Scandals Are Sought," 196, note 150.

157. Ibid.

158. Ibid.

159. Ibid. See also Alexander, "Family Life Conference," 38, note 139.

160. Alexander, "Family Life Conference," 38-47, note 139.

161. Herbie DiFonzo, "Coercive Conciliation: Judge Paul W. Alexander and the Movement for Therapeutic Divorce," University of Toledo Law Review 25 (1994): 537 38. See, for example, Paul W. Alexander, "Legal Sciences and the Social Sciences: The Family Court," Marriage and Family Living 20 (1958): 132-39.

162. Alexander, "Family Life Conference," 38-47, note 139.

163. Ibid., 41-42. 
spouses were often just fed up and wanted "riddance not reconciliation."164 The ABA lawyers nonetheless thought that conciliatory services might be successful in some instances and were central to the plan in any case. ${ }^{165}$ The report further advocated elimination of "defenses" to divorce actions such as "collusion" (mutual consent), "recrimination" (where both spouses were at fault), and "condonation" (where the innocent spouse slept with the guilty spouse after learning about the adultery). ${ }^{166}$ These "revolutionary" changes were to be achieved by procuring "uniformity of divorce legislation through concurrent action by the several States."167

In the end, however, there were only two action items proposed by the ABA delegation to the Family Life Conference: it recommended that the full conference should urge President Truman to appoint a commission to re-examine the laws of marriage and divorce, and that the conference should also express support for specialized family and juvenile courts. ${ }^{168}$ In May of 1948, the full conference accepted the ABA delegation's report with much fanfare, but it took no vote on the recommendations. ${ }^{169}$ In fact, the conference lacked authority to pass binding resolutions. For its part, the ABA's delegation had no intention of endorsing any of the nonlegal recommendations of the conference. ${ }^{170}$ Therefore, the Family Life Conference did not provide a model for moving forward to reform outmoded divorce laws. It just amounted to an exercise in rallying the inner circle of religious, social service agency, and professional troops in an expression of expert opinion on the status and health of the American family.

The report of its delegation to the Family Life Conference yielded few results even within the ABA itself. The ABA created a "Special Committee on Divorce and Marriage Laws and the Family Courts" ("ABA Special Committee"). ${ }^{171}$ That committee spent the first year of its existence futilely attempting to persuade President Truman to appoint a proposed "commission." 172 According to committee member Clarence

164. Ibid., 42.

165. Ibid.

166. Ibid., 43.

167. "Divorce Laws: Remedies for Abuses and Scandals Are Sought," 196-97, note 150.

168. Alexander, "Family Life Conference," 47, note 126; and Kolwyck, "The Ten Year Struggle," 257, note 12. The ABA accepted its delegation's report. "Report of the Delegation of the American Bar Association to the National Conference on Family Life," Annual Report of the American Bar Association 73 (1949): 302.

169. "Report on Divorce Law Acclaimed at National Conference on Family Law," American Bar Association Journal 34 (1948): 448-49.

170. "Divorce Laws: Remedies for Abuses and Scandals Are Sought," 195-96, note 150.

171. Kolwyck, "The Ten Year Struggle," 257, note 12.

172. The autonomous special commission would have included experts from the fields of law, religion, medicine, psychiatry, psychology, sociology, and education. "Report of the 
Kolwyck, the president did not act because he feared criticism from the Catholic Church. ${ }^{173}$ Kolwyck later said that the ABA Special Committee was "foredoomed to failure; indeed it produced no concrete outcome from its years of seeking further action." 174 A different autonomous "inter-professional commission" that was established in 1950 and was supposed to report to NCCUSL likewise fizzled out after years of futility. ${ }^{175}$ Thus, by mid-century, despite anxieties about divorce and archaic divorce law, the legal establishment apparently lacked the will to do anything about it.

Special Committee on Divorce and Marriage Laws and Family Courts," Annual Report of the American Bar Association 75 (1950): 272.

173. Kolwyck, "The Ten Year Struggle," 258, note 12.

174. Ibid., 259.

175. See "Report of the Special Committee on Divorce and Marriage Laws and Family Courts," 272-74 (reporting on the autonomous interprofessional commission of 1950 that comprised more than 100 experts and professionals from the field of law and other professions, including NAWL's N. Ruth Wood); "Report of the Special Committee on Divorce and Marriage Laws and Family Courts," Annual Report of the American Bar Association 76 (1951): 356 (recommending continuation of the ABA's "Special Committee" under receipt of small grant); "Report of the Special Committee on Divorce and Marriage Laws and Family Courts," Annual Report of the American Bar Association 77 (1952): 289 (recommending continuation of committee); "Report of the Special Committee on Divorce and Marriage Laws and Family Courts," Annual Report of the American Bar Association 78 (1953): 302 (recommending continuation of the committee even though work had been stymied because of a lack of funds); "Report of the Special Committee on Divorce and Marriage Laws and Family Courts," Annual Report of the American Bar Association 79 (1954): 324 (recommending continuation of the committee and noting development of incidental functions because of the lack of a family law section in the ABA); "Report of the Special Committee on Divorce and Marriage Laws and Family Courts," Annual Report of the American Bar Association 80 (1955): 319 (recommending that the committee be continued until such time as a family law section is established, and be discontinued thereafter); "Report of the Special Committee on Divorce and Marriage Laws and Family Courts," Annual Report of the American Bar Association 81 (1956): 326 (recommending that the committee be continued until such time as a family law section is established, and be discontinued thereafter); and "Report of the Special Committee on Divorce and Marriage Laws and Family Courts," Annual Report of the American Bar Association 82 (1957): 331 (recommending that if and when the Family Law Section is established, the Committee should be discharged). The ABA approved the establishment of the Family Law Section in 1956, subject to the proviso that a sufficient number of ABA members expressed an interest in the section. Paul W. Alexander, "Not the Least Item': A Section of Family Law," American Bar Association Journal 42 (1956): 733. HALEM, supra note 14 , at 229 credits them with working "to create a model law to rectify the divorce problem" and with at least partially with the establishment of more family and conciliation courts (doesn't mention NAWL). 
While the ABA's Special Committee dithered, NAWL forged ahead with drafting its model bill. ${ }^{176}$ Now under the leadership of Matilda Fenberg of Chicago, ${ }^{177}$ by 1950, NAWL's Uniform Divorce Law Committee had a working version ready for consideration by a conference of local bar and community groups in Cleveland, Ohio. ${ }^{178}$ In 1951, a Chicago Bar Association subcommittee that included Fenberg used her ideas "as a structural basis" for a "Proposed Uniform Divorce Bill."179 Fenberg subsequently reported on it to NAWL, which formally adopted and approved "the principles and draft" at its 1952 annual meeting. ${ }^{180}$

The full text of the approved version of the bill was published in the Women Lawyers Journal in 1952. ${ }^{181}$ The "Whereas" section declared three policies and concerns. First, the divergent divorce laws among the states were confusing, unsatisfactory, and not uniform. As a result, the validity of subsequent marriages "frequently" was called into question, and rights in property were clouded. ${ }^{182}$ Second, the continuation of a marriage between two parties "which has become unbearable" to them, "may be unfair to the children, if any, and may be of no value to the State."183

176. NAWL held lengthy discussions on "suggestions for some provisions of uniform divorce law" at its 1948 annual convention. N. Ruth Wood, "Principles of a Modern Uniform Divorce Law," Women Lawyers Journal 34 (1948): 10. Based on these discussions, the proposed principles were sent to NAWL members and to professors of law. In "Principles of a Modern Uniform Divorce Law," N. Ruth Wood (then-Chair of the NAWL Committee on Marriage and Divorce Law) also drew from articles by Judge Alexander, Reginald Heber Smith, and others who also accepted the new premises, even if they disagreed on some of the details. Ibid.

177. Born in Grajewo, Poland, Matilda Fenberg was a Chicago trial lawyer who briefly practiced with Clarence Darrow. "Matilda Fenberg, Practiced Law with Clarence Darrow," St. Petersburg Times, October 26, 1977, 12B. She wrote a book on women and jury service and in later years headed the Illinois Committee on the ERA. She was the author of the Illinois uniform divorce bill. Ibid.

178. Matilda Fenberg, "Proposed Uniform Divorce Bill," Women Lawyers Journal 38 (1950): 11.

179. "Proposed Uniform Divorce Bill," Women Lawyers Journal 38 (1952): 32. See also Fenberg, "The Uniform Divorce Bill," 248, note 125 (the Matrimonial Law Committee of the Chicago Bar Association created a subcommittee that met every week for almost 2 years to revise the original draft presented to them).

180. See Smith, "A Century of Achievement: The Second 50 Years," 26, note 5. (NAWL's 1947 convention voted to draft and promote a no-fault divorce bill that was prepared by Matilda Fenberg, working with NAWL past-presidents Helen M. Cirese and J. Helen Slough. The bill was approved at the 1952 NAWL convention.) See also Raggio, "Women Lawyers in Family Law," 511, note 12.

181. "Toward Uniform Divorce Laws," Women Lawyers Journal 38 (1952): 15-20 (prefaced by an "Introduction").

182. Ibid. 17, '2a ("Whereas" clause).

183. Ibid., 17, '2b. 
Third, a decree of divorce "ought" to be granted when the court "in its sound discretion" finds "that there is no reasonable possibility of reconciliation ... and that the welfare of [the husband, wife, and children, if any] will be promoted by the divorce." 184

Even though there was a relatively minor incidence of such divorces, the evils of migratory divorce had preoccupied divorce critics for the past 50 years. An explanatory "Introduction" that accompanied the text of the bill in the 1952 issue of the Women Lawyer's Journal remarked that migratory divorce often meant that the spouses might be validly divorced in one state but "upon remarriage, subject to prosecution for bigamy in another." 185 This was close to the facts of the Supreme Court's Williams v. North Carolina decisions of 1942 and 1945.186 Those cases did not concern the substance of domestic relations law. Rather, they were about the Full Faith and Credit Clause of the United States Constitution. In Williams I the Court overruled Haddock and abandoned forever the inquiry into which spouse was at "fault" for disruption of the "marital domicile" as a determinant of jurisdiction for divorce. ${ }^{187}$ The Court instead held that jurisdiction was solely "dependent on the relationship which domicil [sic] creates and the pervasive control which a state has over marriage and divorce within its own borders." 188 In other words, as long as the migratory state became the "domicile" of at least one spouse, it could grant a divorce, and a sister state had to recognize that decree. ${ }^{189}$ "Fault" was irrelevant and no longer of constitutional moment. Williams II, however, created a caveat. If the first proceeding was ex parte (that is, one in which only one spouse appeared in court), the home state still had an opportunity to inquire into the veracity of the alleged domicile in the migratory state. ${ }^{190}$ The latter ruling, however, did not change the beachhead for "no-fault" that the Supreme Court created in the law of jurisdiction. ${ }^{191}$

184. Ibid., 17, '2c.

185. "Introduction," in "Toward Uniform Divorce Laws," 15-17, note 181. This Introduction was based on the report of Matilda Fenberg, who had chaired NAWL's Uniform Divorce Bill Committee from 1950 through 1952. Ibid., 15.

186. 317 U.S. 287 (1942) (“Williams I'); Williams v. North Carolina, 325 U.S. 226 (1945) ("Williams II"). The couple who divorced in Nevada and remarried each other there were convicted of "bigamous cohabitation" when they came back to North Carolina to live with each other.

187. Williams I, 317 U.S., 304.

188. Ibid., 300.

189. Ibid., 302-3.

190. Williams II, 325 U.S., 239.

191. The somewhat confusing result of this ruling was that each state's conclusion prevailed within its own boundaries. Ibid. In later rulings, the Court distinguished jurisdiction 
The "Introduction" published with NAWL's bill did not rely on this implication of the Williams cases. NAWL proposed to control the migratory divorce phenomenon by uniform statute. The bill, therefore, incorporated a moderately long minimum period of 6 months' "domicile" in order to file a divorce suit. ${ }^{192}$ If adopted by many states, that would mean that the longest requirements in the strictest states would be substantially shortened, but that divorce mills with their much shorter times would be put out of business. ${ }^{193}$ The divorce haven states were unlikely to sign on to this proposal. ${ }^{194}$

As a matter of the substance of divorce grounds, NAWL sought to supplant "fault." It proposed to replace the traditional model of divorce based on guilt, punishment, and adversarial confrontation with a more conciliatory and "therapeutic" approach. ${ }^{195}$ The bill's move away from guilt and punishment, however, was quite cautious. It eliminated the adversarial styling of a divorce case. ${ }^{196}$ It rephrased the traditional grounds for divorce in terms of less loaded terms and then applied the court's discretion to all these grounds. ${ }^{197}$ The new bases for divorce were "mutual fidelity" (equivalent to adultery pursuant to the definition section of the bill); "mutual respect" (equivalent to extreme and repeated physical cruelty or mental cruelty resulting in physical injury); "mutual right of consortium" (willful desertion or habitual drunkenness or imprisonment); mental or sexual incapacity on the part of either party; or another spouse of either party living at the time of the marriage (bigamy). ${ }^{198}$ The court could grant a divorce only

to divide property from domicile for divorce, requiring personal jurisdiction over both parties for the former. Thus, it created what it called the "divisible divorce." Sherrer v. Sherrer, 34 U.S. 343 (1948) and Coe v. Coe, 334 U.S. 378 (1948) (ruling that migratory divorce decree was entitled to full faith and credit where the defendant appeared in the divorce proceeding); and Estin v. Estin, 334 U.S. 541 (1948) (ruling that New York was not required to give full faith and credit to a Nevada proceeding in which the wife did not appear, creating the divisible divorce).

192. As a general matter, "[t]he fact that a stay in a state is not for long is not necessarily fatal to the existence of a domicil .... [T] he 'essential fact that raises a change of abode to a change of domicil is the absence of any intention to live elsewhere.' The intention to stay for a time to which a person 'did not then contemplate an end' was held sufficient." Williams I, 317 U.S., 299.

193. "Introduction," in "Toward Uniform Divorce Laws," 18, '5, note 181.

194. In addition, Section 24 was designed to promote voluntary recognition of decrees by sister states. Enacting states undertook to give full faith and credit to the decrees of sister states. Ibid., 20, 24.

195. Ibid., 15-16. See also Michael Levin, "Proposed Uniform Divorce Bill," Women Lawyers Journal 39 (1953): 3-4.

196. "Toward Uniform Divorce Laws," 18, '9, note 181.

197. Ibid., 17-18, "7 (Grounds for Divorce) and 3 (Definitions).

198. "Toward Uniform Divorce Laws," 17-18, "7 and 3.3-3.09, note 181. Michael Levin (of the Chicago Bar committee that considered Matilda Fenberg's proposal) compared this to 
if it found in the exercise of its reasonable discretion that any one of these grounds was established and that the "marriage cannot be preserved with benefit because its continuation is unbearable to the parties or unfair to the children, if any, and of no value to the State."199

The bill thus contained a mixture of old and new and can be considered only a transitional proposal. Whatever the nomenclature, the bill in essence required courts to find one of the old familiar grounds against one of the spouses. ${ }^{200}$ On the other hand, it openly announced that marriages that were unbearable to the parties should not be continued. ${ }^{201}$ In a critical step away from allowing "fault" to block a divorce, the statute also omitted the traditional "defenses" such as collusion, condonation, or recrimination. Section 8.01, however, instructed the court that in determining whether or not the named grounds existed it could not rely on the petitioner's own "misconduct." 202 Therefore, the bill did not provide for unilateral divorce that could be obtained by either spouse acting on his or own desires regardless of circumstances or responsibility for occasioning the grounds.

Although the renamed grounds arguably constituted only a generous "restatement" of the law of divorce prevalent in many states, ${ }^{203}$ NAWL believed that the conciliation provisions proposed a real change in divorce procedure. ${ }^{204}$ For the women lawyers, this was the heart and soul of the bill's innovation. ${ }^{205}$ The bill's "therapeutic" mandate was expressed by "conciliation" requirements that had become more mandatory in final

\footnotetext{
"the usual grounds found in most of the states, such as adultery, cruelty, legally adjudicated mental illness." He explained why the bill contained these grounds: "It was felt necessary and desirable to set up minimum grounds in order to avoid the vesting of absolute discretion in the court in this phase of divorce in order to prevent the possible abuse of this discretion." Levin, "Proposed Uniform Divorce Bill," 4, note 195.

199. “Toward Uniform Divorce Laws," 18, '8 ("Divorce, When Granted"), note 181.

200. Ibid., 17-18, "7 and 3.3-3.09.

201. Ibid., ' $2 c$ (recognizing that a decree of divorce "ought" to be granted when the Court "in its sound discretion" finds "that there is no reasonable possibility of reconciliation ... and that the welfare of [the husband, wife, and children, if any] will be promoted by the divorce").
}

202. See Henry H. Foster, Jr., "Divorce Reform and the Uniform Act," Family Law Quarterly 7 (1973): 179, 181 (assuming that there are no common-law defenses to divorce in the new bill).

203. Levin, "Proposed Uniform Divorce Bill," 3, note 195 (The bill "[was] not as revolutionary as appears at first glance").

204. Ibid., 3-4 ("It is new chiefly in its attitude and treatment of divorce and in the "therapeutic approach' which has been adopted. Otherwise, the Bill represents a restatement and codification of the best case law and statutory law to be found throughout the forty-eight states.")

205. Fenberg, "The Uniform Divorce Bill," 248 (claiming that "the most outstanding feature of this Uniform Divorce Bill is the therapeutic approach which it adopts"), note 125. 
form than they had been in a $1950 \mathrm{draft}^{206}$ Courts were directed to attempt reconciliation "in every case" and to offer "conciliation services," through "private and confidential consultation and conference with the parties."207 Before any "hearing may be set," the divorce court could require the parties to use its court-attached conciliation services "where feasible" and could even mobilize outside social service agencies at its own discretion, provided that any report thereby generated did not become part of the record and that any facts in the report were not considered in a hearing "unless established by competent evidence, subject to the right of cross examination and to the right of presenting contrary evidence." 208 One or more pre-hearing conferences, moreover, were mandatory. ${ }^{209}$ They were to be conducted through "mediation" rather than through "contest." 210

Ideas about "therapeutic divorce, administered by family courts composed of equal parts of sheriff and social worker, counselor and judge" emerged after World War II." 211 Although not a new concept, very few family courts had been established before then. ${ }^{212}$ Judge Paul W. Alexander, who succeeded Reginald Heber Smith as the chair of the ABA's delegation to the Family Life Conference of 1948, was the foremost proponent of the family court movement from the 1940s to the $1960 \mathrm{~s}^{213}$ His theories substituted a marital illness paradigm in place of guilt or

206. Compare "Toward Uniform Divorce Laws," 17, "12-13, note 181, with a 1950 draft. Sections $12-13$ of the final version approved by NAWL provided that "The Court in every case shall seek to effect a conciliation of the parties by private and confidential consultation and conference with the parties. In this effort, the Court, where feasible, shall require the use of its conciliation services, and in its discretion the social agencies available to the Court, before a hearing may be set on the petition." Section 8 of the 1950 version read as follows: "The court shall, wherever practicable, seek to effect a conciliation of the parties by private and confidential consultation and conference with the parties. The court shall makes its conciliation services available upon the request of the parties, or either of them, and may in its discretion, require the use of its conciliation services before a hearing is set on the petition." Fenberg, "Proposed Uniform Divorce Bill," 12-13, note 178.

207. "Toward Uniform Divorce Laws," 18, '12 (“Conciliation Services"), note 181.

208. Ibid.

209. Ibid., 18, '13 ("Prehearing Conferences").

210. Ibid.

211. DiFonzo, Beneath the Fault Line, 114, note 14. Lynne Halem traces the earlier origins of a "medical model of a therapeutic court" in the juvenile court movement and its expansion to the family unit in domestic courts. Ibid., 115-17. She argues that "the clinical notion of divorce and the effort to restructure the legal system into a therapeutic forum was still in an embryonic state in the 1920s and 1930s" but that "the attempt to form a workable union between psychiatry and the law continued as the clinical movement picked up momentum in the post-World War II era." Ibid., 157.

212. Ibid., 114.

213. Ibid. 
innocence and sought expert help to heal troubled families. ${ }^{214} \mathrm{~J}$. Herbie DiFonzo has described Alexander's approach as "coercive conciliation."215 New Jersey, one of those few jurisdictions that attempted the model, quickly abandoned it in 1957 as a "massive failure." 216

NAWL's uniform bill, of course, was not a family court proposal. ${ }^{217}$ However, it did use the "therapeutic" language that became increasingly popular after World War II. It was designed to readjust judicial machinery at a time when the old procedures had come into considerable public disrepute and no longer fit the temper of the times. As the Women Lawyers Journal's "Introduction" to the NAWL bill explained, the charges and countercharges required under traditional divorce law threatened "decency and respectability" to the point where, if they had to separate, the ex-spouses were left with an unfortunate legacy of "indignity, hostility, bitterness and aggression." 218 Existing divorce laws made the spouses into opponents who engaged in a battle over who was guilty and who was innocent. ${ }^{219}$ Although it was impossible to eliminate the causes of "marital disharmony" because they were "deeply rooted in the nature of human beings, the mores of society and in our economic and social life," new legislation might help to preserve a marriage or, if that were not possible, to provide a respectable divorce. ${ }^{220}$

The "Introduction" further explained the proposed mechanism that courts would use to achieve the change in attitude and philosophy. The bill would substitute "conciliatory procedure" for punishment, much as juvenile courts were meant to do.221 "Similarly" to those institutions, divorce courts "should endeavor first to ascertain the cause of the break-up and then to seek a remedy" with the help of experts such as "clergymen,

214. Ibid., 116. Proponents of this extreme view of therapeutic divorce did not favor either living separate and apart or incompatibility as grounds for divorce. Ibid., 118-19.

215. DiFonzo, "Coercive Conciliation," 8. For the Report to the Family Life Conference and coercive conciliation and links to the Juvenile Court paradigm, see, DiFonzo, Beneath the Fault Line, 125-28, note 14.

216. DiFonzo, Beneath the Fault Line, 136, note 14. But see Riley, Divorce: An American Tradition, 162 (the most well-known of these courts, the Los Angeles Children's Court of Conciliation, reported that they reconciled $43 \%$ of alienated parents who appeared before them in 1959), note 21.

217. The original proposal for California's no-fault reform of 1969 included a unified family court as a counterbalance to the new liberal marital breakdown standard for divorce. Kay, "A Family Court: The California Proposal," 1225-26, note 15. The provision was dropped in the legislative process. Jacob, Silent Revolution, 59, note 10.

218. "Toward Uniform Divorce Laws," 16 ("Introduction"), note 181.

219. Ibid., 15.

220. Ibid.

221. Ibid., 16. 
psychiatrists, sociologists." 222 With this assistance, the spouses might cease to be "squared off like prizefighters in a ring" but instead be "encouraged to collaborate in rebuilding for the future welfare of the family." 223 The judge's role in all of this was to review the "complete family record" and to make a decision "with the family welfare in mind." 224 If the judge concluded that divorce was necessary, then "it should not be because one party or the other is guilty, but because the marriage has become unbearable to the parties, unfair to the children, if any, and of no value to the state." 225 In other words, the law would try to treat the failing marriage, or at least facilitate a "healing" divorce. ${ }^{226}$

In support of its proposal, NAWL argued that its uniform bill did not constitute a major break with existing substantive law:

The proposed Bill is not as revolutionary as appears at first glance. It is new chiefly in its attitude and treatment of divorce and in the "therapeutic approach" which has been adopted. Otherwise, the Bill represents a restatement of the best case law and statutory law to be found throughout the forty-eight states. ${ }^{227}$

Somewhat inconsistently, the proponents of the "therapeutic approach" also claimed that the reform was innovative in correcting the "outstanding defect" of "existing divorce laws in all states," the necessity to prove innocence or guilt. ${ }^{228}$

It is difficult to offer a cogent critique of NAWL's bill in the context of its own times without slipping into the habits of hindsight and ahistoricism. Clearly, like other critics of the day, NAWL was proclaiming as a "new" premise a view that was becoming widely accepted but that was not embodied in formal law yet. ${ }^{229}$ The approach denied that divorce was a punishment to be awarded against those guilty of sin. Contemporaries more and more saw divorce as a mark of a marriage that had already failed.

222. Ibid. The ABA delegation to the National Conference on Family Life in 1948 had recommended the establishment of family courts presided over by specialized judges who would be aided by a staff of experts. "The Administration of Divorce: A Philadelphia Study," University of Pennsylvania Law Review 101 (1953): 1224-25. See also Charles L. Chute, "Divorce and the Family Court," Law and Contemporary Problems 18 (1953): 49-65 (discussing various specialized courts in different states and the ABA delegation report).

223. "Toward Uniform Divorce Laws," 16 ("Introduction"), note 181.

224. Ibid.

225. Ibid.

226. Ibid.

227. Fenberg, "Our Proposed Uniform Divorce Bill," 12, note 7.

228. "Toward Uniform Divorce Laws," 13 ("Introduction"), note 181.

229. Matilda Fenberg, "Our Uniform Divorce Bill," 12 (describing their proposal as "a bill such as had never been drafted before"), note 10 . 
This analysis was reflected in the classic article written by NAWL's Ruth Wood in 1947, it was echoed in the 1948 report of the ABA's delegation to the Family Life Conference, and it was a key concept of the Uniform Divorce Law Bill that NAWL endorsed in 1952 and that it pressed on NCCUSL and the states in the years thereafter. As the bill's primary drafter Matilda Fenberg explained again in 1961, the reforms recognized that fault already was an outmoded basis for divorce.

The purpose of our Bill is not to make divorce easier or more difficult. It is simply to substitute truth for deception, common sense for technicalities, and to give the Courts real opportunities to prevent marriage failures by means of conciliation and treatment, rather than to punish failures in marriages. ${ }^{230}$

Fenberg acknowledged that existing "penalty laws and laws prohibiting divorce are impractical and unsound." 231 Indeed, participants would simply refuse "to enact or enforce or to obey them." 232 In other words, the reforms would conform practice to reality, and have the added bonus of affording an opportunity for conciliatory intervention.

Versions of NAWL's model bill were introduced in a handful of individual states between 1953 and 1958, but without success. ${ }^{233}$ On the national front, the politics of the legal establishment obstructed consideration. NAWL's attempt to present its uniform bill to NCCUSL was stymied when the commissioners told Fenberg that they could only receive bills or suggestions for bills from committees of the ABA. ${ }^{234}$ But there was no Family Law Section at the time, and without it, NCCUSL was not going to consider NAWL's bill or act at all. ${ }^{235}$ Together with its allies in the ABA, NAWL struggled for years before finally achieving establishment of the Family Law Section in 1958. ${ }^{236}$ Pioneer Section Officer Clarence Kolwyck later exclaimed "And I

230. Ibid., 14.

231. Ibid.

232. Ibid.

233. Fenberg, "Our Uniform Divorce Bill," 14 (bill introduced between 1953 and 1958 in Georgia, Oregon, Tennessee, Arkansas, and Wisconsin, and brought up for discussion in California and some other states), note 10 .

234. Fenberg, "The Status of the Proposed Uniform Divorce Bill," 10, note 11. See also Fenberg, "Our Uniform Divorce Bill," 12, note 10.

235. Raggio, "Women Lawyers in Family Law," 510, note 12.

236. See Godfrey L. Munter, "Report of the Special Committee to Investigate the Advisability of an ABA Section of Family Law," Women Lawyers Journal 43 (1957): 17. See also Kolwyck, "The Ten Year Struggle," 262, note 12; Raggio, "Women Lawyers in Family Law," 510, note 12; Fenberg, "The Status of the Proposed Uniform Divorce Bill," 10, note 11; and "The Family Law Section Celebrates Its Silver Anniversary," Family Advocate 6 (1983-84): 35-37. 
hope the point is not missed in what I have said that but for women lawyers, we may not have attained sectionhood." 237

With the creation of the Family Law Section, the Uniform Divorce Reform Bill in theory could surmount the artificial hurdles set by NCCUSL. In 1957, Fenberg explained how the NCCUSL process likely would affect the NAWL bill going forward. ${ }^{238}$ She anticipated that as always, there would be changes in the bill throughout the drafting process. ${ }^{239}$ NCCUSL would consider proposals, produce its own draft, and then present it to the ABA for its approval before distributing the final model law to be considered by state legislatures. Accordingly, NAWL's Bill was introduced to the ABA in 1960 and forwarded to NCCUSL at long last. ${ }^{240}$ Fenberg understandably expected that "finally and of necessity" their proposal would "become the basis of any bill drafted by the National Conference of Commissioners on Uniform State Laws."241 But that did not happen. Instead, new initiatives that were not connected to NAWL's project overtook events. The California State Legislature began its own inquiry into divorce reform in 1963, the same year that Betty Friedan first published her feminist classic, The Feminine Mystique. ${ }^{242}$ When some influential matrimonial attorneys became involved in NCCUSL's process in 1965 and a special drafting committee began work in 1967, there was no apparent link between that work and the NAWL proposal already on the table. Accompanied by deep fissures both within and without its ranks, ${ }^{243}$ NCCUSL promulgated the UMDA in 1970, as amended in 1971 and 1973. Together with the California statute that had been enacted in 1969, the no-fault divorce revolution had begun in earnest.

237. Kolwyck, "The Ten Year Struggle," 262, note 12.

238. Fenberg, "The Status of the Proposed Uniform Divorce Bill," 10, note 11.

239. Ibid.

240. Raggio, "Women Lawyers in Family Law," 510, note 12.

241. Fenberg, "Our Uniform Divorce Bill," 15, note 10.

242. Kay, "From the Second Sex to the Joint Venture," 2050-51, note 15. See also Howard A. Krom, "California's Divorce Law Reform: An Historical Analysis," Pacific Law Journal 1 (1970): 156.

243. See, for example, Felix Infausto, "1971 Mid-Year Report and Recommendation of the Family Law Section to the ABA House of Delegates on the Uniform Marriage and Divorce Act," Family Law Quarterly 5 (1971): 133-203 (recommending that ABA reject the draft in its present form). For conflicting views on the proposal, see Maurice H. Merrill, "Section 305: Genesis and Effect," South Dakota Law Review 18 (1973): 538, 539; Foster, "Divorce Reform and the Uniform Act," 185, note 202; and Ralph J. Podell, "The Case For Revision Of The Uniform Marriage And Divorce Act," South Dakota Law Review 18 (1973): 601, 603-4, 609. 


\section{NAWL and Divorce Reform in the 1950s: Revolutionary, Domestic, Quiescent?}

What can be learned from the lost history of NAWL and its "greatest project"? First, where does it fit in the narrative of the history of divorce? In defense of its 1952 proposal, NAWL maintained that its "no-fault" reform was not so "revolutionary. ${ }^{244}$ Twenty years later, the same question was asked about the no-fault revolution of the 1970s. Starting with the California law of 1969 and NCCUSL's UMDA of 1970, marital breakdown laws spread like "prairie fire." ${ }^{245}$ Despite the statutory transformations, some commentators have questioned whether no-fault divorce was designed to be radical at all. ${ }^{246}$ Critics have argued that the changes only amounted to a formal and rhetorical assimilation of the law on the books to the law in action; that is, to the existing practice of collusive lawsuits and migratory divorce. ${ }^{247}$ Although NAWL's 1952 bill stopped considerably short of incorporating genuine no-fault grounds, NAWL's avowed desire to use reform "to substitute truth for deception" 248 lends some credence to the "no-fault" is "no revolution" argument about the 1970s. The lost history reinforces the view that, whatever the ultimate consequences, the move to no-fault in the 1970s began as a "last gasp" attempt by "conservative reformers" to retain judicial control over the burgeoning divorce rates that manifested after World War II, plateaued in the $1950 \mathrm{~s}$, and then surged to new heights in the 1960s. ${ }^{249}$

By contrast to no-fault grounds per se, NAWL insisted that its procedural proposals for conciliatory and "therapeutic" divorce were truly innovative. ${ }^{250}$ How does this part of NAWL's divorce reform story fit into the "domesticity" narrative that so often has been told about the 1950s? Elaine Tyler May called the 1940s and 1950s "a unique twenty-year era of

244. Fenberg, "Our Proposed Uniform Divorce Bill," 12, note 7.

245. Lynn D. Wardle, "No-Fault Divorce and the Divorce Conundrum," Brigham Young University Law Review 1991 (1991): 79, 87-88.

246. A contrasting view holds that although the focus was on the changes in the grounds for divorce, the real revolution occurred in the statutory measures for mandatory division of property between the divorcing spouses. Brett R. Turner, 1 Equitable Distribution of Property, 3D (November 2017 Update), '1.3.

247. See, for example, Fineman, The Illusion of Equality, 31-32, note 16 (distinguishing Weitzman, The Divorce Revolution, note 16, and Jacob, Silent Revolution, note 10). Fineman argues that the real "revolution" came afterwards with "subsidiary changes in the laws governing the economic relations between divorcing spouses and the rules and standards applied to custody determinations." Fineman, The Illusion of Equality, 32.

248. Fenberg, "Our Uniform Divorce Bill," 14, note 10.

249. Caldwell, "Not Ozzie and Harriet," 2, note 12.

250. Fenberg, "The Uniform Divorce Bill," 248, note 125. 
domesticity" and Jessica Weiss also emphasized the "singularity of the 50s family." 251 May linked domestic ideology to an "apolitical" and "therapeutic" approach..$^{252}$ Although NAWL's model of therapeutic divorce may be compatible with this account of family-centered domesticity in the 1950s, it does not support the claim that the decade's "singularity" shaped the call for divorce reform. The demand for legal reform had its own momentum. By the time of the postwar spike in the divorce rate in 1946, it already was clear that the central problem was that restrictive formal law did not match the much more liberal collusive practice. Insiders in the ABA shared NAWL's concerns about this disjunction, but committee meetings produced no "concrete outcome." 253 NAWL, on the other hand, launched its initiative soon after World War II, when divorce rates were soaring, but then pursued it through the 1950s, when the pace leveled off. Therefore, its campaign for uniform no-fault reform appears unrelated to any phenomenon of heightened "domesticity" in the 1950s.

When no-fault finally broke through in 1969 and 1970, it was without most of the conciliatory and "therapeutic" procedures that NAWL so prized. California's proposal originally called for integration of "the [marital] breakdown principle with a comprehensive plan for marriage and divorce counseling to be made available through the family court in cooperation with private and community facilities." 254 Even if "marriage counseling" did not work, the procedures then could be used for "divorce counseling," especially where children were involved. ${ }^{255}$ As enacted by the California Legislature in final form, however, the 1969 act dropped the entire apparatus of a family court, including professional staffing and counseling, and also limited procedural delays designed to encourage conciliation. ${ }^{256}$ Similarly, after much dispute and negotiation in the process of drafting the UMDA, the National Conference of Commissioners made only minor concessions to the ABA's call for more court-involved conciliation and procedural delay. ${ }^{257}$ It is no accident that the unsuccessful battle for those provisions was led by the ABA's Family Law Section, the entity

251. May, "Pushing the Limits, 1940-1961," 237, note 24; and Weiss, To Have and to Hold, 4, note 18.

252. May, Homeward Bound, 17, note 24.

253. Kolwyck, "The Ten Year Struggle," 259, note 12.

254. Kay, "A Family Court: The California Proposal," 1225-26, note 15.

255. Ibid., 1228-30.

256. Jacob, Silent Revolution, 59, note 10; and Kay, "An Appraisal of California's No Fault Divorce Law," 299, note 15.

257. For the bitter controversy between the Uniform Commissioners and the Family Law Section of the ABA, see Harvey L. Zuckman, "The ABA Family Law Section v. The NCCUSL: Alienation, Separation, and Forced Reconciliation Over the Uniform Marriage and Divorce Act," Catholic University Law Review 24 (1974): 61, 62. 
that owed its very existence to NAWL's campaign in the 1950s and that shared its cautious values. In a sense, this defeat of the Family Law Section also amounted to a final repudiation of the spirit of NAWL's pioneering proposal. Nonetheless, both California's Family Law Act and UMDA left the judges in charge. They had final discretion to decide whether or not the marriage had broken down. Ironically, in the end, this had the practical effect of promoting unilateral divorce. Courts proved willing to take the word of only one spouse about the breakdown of the marriage and, therefore, to grant a divorce without the mutual consent of the parting couple. ${ }^{258}$ In the aftermath of this unexpected outcome, the use of mediation and other nonadversarial techniques to resolve controversies related to divorce eventually spread, especially with respect to disputes involving children. ${ }^{259}$

Along with "domesticity," the decade of the 1950s also has been stereotyped as a time of "quiescence" for American women and of "doldrums" in the women's rights movement. What does the lost history reveal about feminism and divorce reform or about women's rights activism in the midtwentieth century? There is no clear-cut answer to the first part of the question. Historically, favoring easier divorce was problematic for the women's movement. The 1848 Declaration of Sentiments listed divorce among its indictments of laws that oppressed women, but Elizabeth Cady Stanton failed in her effort to make divorce reform part of the women's rights agenda. ${ }^{260}$ In the late nineteenth and early twentieth centuries, the close alliance between the women's suffrage and the temperance movements further complicated matters. ${ }^{261}$ Thus, in contrast to efforts to reform the laws

258. Grace Ganz Blumberg, "Reworking the Past, Imagining the Future: Jacob's Silent Revolution," Law \& Social Inquiry 16 (1991): 115, 122; Weitzman, The Divorce Revolution, 19, note 16 (none of judges interviewed had ever denied a petition for divorce); and ibid., 26-28 (no-fault divorce in California required no consent and was unilateral).

259. See, for example, Barbara Glesner Fines, "Fifty Years of Family Law Practice- the Evolving Role of the Family Law Attorney," Journal of the American Academy of Matrimonial Lawyers 24 (2012): 391, 406; Debra Berman and James Alfini, "Lawyer Colonization of Family Mediation: Consequences and Implications," Marquette Law Review 95 (2012): 887, 889; and John Lande, "The Revolution In Family Law Dispute Resolution," Journal of the American Academy of Matrimonial Lawyers 24 (2012): 411, 424.

260. Stanton was the most outspoken of the first feminists in the demand to make divorce more available and on terms more favorable to women. She was unable to gain support at the women's rights convention at Seneca Falls for her proposal to liberalize divorce law. Elizabeth B. Clark, "Matrimonial Bonds: Slavery and Divorce in Nineteenth-Century America," Law and History Review 8 (1990): 25.

261. See, for example, Suzanne M. Marilley, "Frances Willard and the Feminism of Fear," Feminist Studies 19 (1993): 123. (Although she was an important supporter of women's suffrage, the leader of the temperance movement Frances Willard was equally adamant in her opposition to liberal divorce laws.) 
of marriage so as to make them fairer to women, divorce reform, historically, was not a necessary component of the feminist agenda.

As this study has shown, despite their long-standing preoccupation with divorce law, the women lawyers of NAWL also did not link their "greatest project" to an express demand for gender equality. Interestingly, the no-fault reformers who followed NAWL approximately 20 years later have conceded that even at the very cusp of the revived mass movement for women's rights in 1969 and 1970, they did not have gender equality in mind either. ${ }^{262}$ Feminists, however, took part in some of the state battles about new rules of marital property distribution and alimony associated with no-fault reform. For example, a group of attorneys in New York held hearings in 1972 on the potential financial consequences of the proposals. $^{263}$ Betty Berry, the Coordinator of New York National Organization for Women (NOW)'s Committee on Marriage and Divorce, wrote an "Equal Rights Divorce Reform" bill that called for equal division of marital property. ${ }^{264}$ She also was prepared to accept equitable distribution as incorporated in the UMDA instead, as long as any legislation supplanted the unfair common law rules of allocation by ownership of title. ${ }^{265}$ Divorce reform, however, was not a priority for NOW at this time. ${ }^{266}$ In Wisconsin, feminists who were "actively involved in the [divorce] reform effort and leaders in the successful ERA ratification effort...prevented enactment of a no-fault provision until legislators built financial protections for women into the divorce reform package." 267

After the spread of no-fault statutes, the unexpected economic and social consequences became a feminist flashpoint. In 1985, sociologist Lenore Weitzman published a study of California's decade under no-fault. It quickly became "front page news." 268 She claimed that no-fault amounted to unilateral divorce (rather than divorce by mutual consent) and deprived many divorcing wives of bargaining leverage. ${ }^{269}$ Weitzman argued that

262. See, for example, Kay, "An Appraisal of California's No Fault Divorce Law," 293, 299-304, note 15; and Levy, "A Reminiscence about the Uniform Marriage and Divorce Act," 53, note 15 .

263. Mary Ziegler, "An Incomplete Revolution: Feminists and the Legacy of Marital Property Reform," Michigan Journal of Gender and Law 19 (2013): 259, 271.

264. Ibid.

265. Ibid.

266. Ibid., 272-74.

267. Kay, "From the Second Sex to the Joint Venture," 2061, note 15. "After the no-fault divorce law was enacted in 1977, [feminists] ... continued to work for reform of Wisconsin's common law property system," and Wisconsin later became the only common law state to adopt the Uniform Marital Property Act. Ibid., 2062.

268. Ibid., 2066.

269. Weitzman, The Divorce Revolution, 26-31, note 16. 
combined with other accompanying legal changes, no-fault had an adverse effect on California's divorced women and their children. ${ }^{270}$ Feminists and other family law experts have debated the accuracy and extent of the claimed link between the move to no-fault and these unfortunate outcomes ever since. ${ }^{271}$

Although it may be hard to draw a direct line between early no-fault reform and women's equality theory, the lost history of NAWL's project leads to a more nuanced interpretation of women's activism in the 1950s. Traditional narratives of the history of the women's movement described two waves of heightened activity separated by a lull, including the 1950s. According to this view, the first stage began with the Woman's Rights Convention in Seneca Falls in 1848 and culminated in the passage of the Nineteenth Amendment in 1920. The second wave came with the revival of a mass movement in the mid-1960s. ${ }^{272}$ In between these "waves" was a purported "doldrums" during which the women's

270. See, for example, ibid., 323-56 (describing the relative decline of postdivorce income for women and their children as compared with that of their ex-husbands; the impoverishment of women and children; the social consequences of stress, isolation, competence, and health; societal consequences; and a "two-tier society").

271. See, for example, Richard R. Peterson, "A Re-Evaluation of the Economic Consequences of Divorce," American Sociological Review 61 (1996): 528, 532; Levy, "A Reminiscence about the Uniform Marriage and Divorce Act," 52, note 15; Marsha Garrison, "The Economics of Divorce: Changing Rules, Changing Results," in Divorce Reform at the Crossroads, ed. Stephen D. Sugarman and Herma Hill Kay (New Haven, CT: Yale University Press, 1990), 75; Herbert Jacob, "Another Look at No-Fault Divorce and the Post-Divorce Finances of Women," Law and Society Review 23 (1989): 95; and Kay, "From the Second Sex to the Joint Venture," 2066-67 (summarizing criticism and replies), note 15 . Weitzman has modified some of her findings and has acknowledged that other factors contributed to the postreform consequences. See Lenore J. Weitzman, "The Economic Consequences of Divorce are Still Unequal: Comment on Peterson," American Sociological Review 61 (1996): 537, 538. Regardless of the merits of the Weitzman thesis, no-fault divorce does not have the same economic significance for many women who already are living in poverty. See, for example, Dorothy E. Roberts, "Racism and Patriarchy in the Meaning of Motherhood," American University Journal of Gender and Law 1 (1993): 1, 23-24. (The "feminization of poverty" analysis obscures the significance of race in poverty by focusing on the "drastic economic losses white middle-class women and children suffer as a result of divorce," whereas most black households were poor before divorce and remain poor thereafter.) Twila L. Perry, "Race Matters: Change, Choice, and Family at the Millennium," Family Law Quarterly 33 (1999): 461, 463-64 (noting that the "downside of no-fault, that it has hurt women economically, clearly has less relevance to the lives of Black women than it does the lives of white women" because black couples typically have less economic wealth to divide).

272. See, for example, "Preface," in Century of Struggle: The Woman's Rights Movement in the United States, ed. Eleanor Flexner (1973), vii; and O'Neill, Everyone Was Brave: A History of Feminism in America, 264, note 59. 
movement was in a state of "abeyance." 273 In their social movement history of the years between 1945 and the 1960s, Leila Rupp and Verta Taylor modified this discontinuous picture in one sense. They focused on what they called an "elite-sustained" movement consisting of "core" organizations that supported the ERA after 1920 and that continued to be active up to and including the 1950s. ${ }^{274}$ They argued that these organizations provided continuity and a home for women's rights activists in the years of abeyance and provided an important "transition" from an earlier stage of the movement to that of the 1960s. ${ }^{275}$ In particular, Rupp and Taylor examined the vicissitudes of Alice Paul's NWP, the center of support for the ERA that she drafted. ${ }^{276}$ The authors concluded that NAWL also belonged in this small "pre-existing core" of the "elite-sustained" movement. 277

Rupp and Taylor's "elite-sustained" account defines women's activism in the postsuffrage middle years narrowly only in terms of support for the ERA. ${ }^{278}$ Today, however, revisionist scholars no longer subscribe to a two-wave narrative. ${ }^{279}$ They find that women's activism extended beyond the ERA's so-called "core" demand. Rather, it encompassed many types of feminists, including women who worked for gender equality in mixed-sex labor and civil rights organizations. ${ }^{280}$ Even when they focus on traditional single-sex women's organizations, the no-wave scholars call into question the doldrums view of the years between suffrage and the 1960s. ${ }^{281}$ This article considers NAWL in this newer frame, but on its own terms. It is of course true that NAWL endorsed the ERA in 1935 and made it a priority in the 1940s and 1950s. ${ }^{282}$ It actively supported the amendment when the great majority of more progressive women's and labor groups opposed it

273. Verta Taylor, "Social Movement Continuity: the Women's Movement in Abeyance," American Sociological Review 54 (1989): 761.

274. Rupp and Taylor, Survival in the Doldrums, 7-9, note 12.

275. Ibid., 7-9.

276. Ibid., 24-44.

277. Ibid, 46.

278. Ibid., 63-64.

279. See, for example, Kathleen A. Laughlin, Julie Gallagher, Dorothy Sue Cobble, Eileen Boris, Premilla Nadasen, Stephanie Gilmore, and Leandra Zarnow, "Is It Time to Jump Ship?," note 33.

280. See, for example, Cobble, The Other Women's Movement, 7, note 34; Meyerowitz, "Chapter 1: Introduction: Women and Gender," in Not June Cleaver, 5-10, note 28: Dorothy Sue Cobble, "Chapter 4: Recapturing Working-class Feminism: Union Women in the Postwar Era," in Not June Cleaver, 57-83.

281. See, for example, "Civil Feminists: The Politics of the Minnesota Federation of Business and Professional Women's Clubs, 1942-1965" in Breaking The Wave.

282. "Editorial," Women Lawyers Journal 22 (1935-36): 38. 
because of its potential to jeopardize hard-won labor law protection. ${ }^{283}$ Clearly, however, the highly divisive ERA was never the full sum of NAWL's agenda nor even, judging by the pages of the Women Lawyers' Journal and the scope of NAWL's committees, the predominant focus of the work of the association. ${ }^{284}$ This lost history demonstrates that even in a so-called "core" postsuffrage organization there was much more to their women's activism. The public and professional concerns of the women lawyers were wide ranging and their self-proclaimed "greatest project" of the 1950s was divorce reform.

As an example of NAWL's universe of concerns, consider its longrunning fight against exclusion of women from jury service, a priority that it shared with most women's organizations across the full range of the spectrum and regardless of their position on the ERA. ${ }^{285}$ Matilda Fenberg, who chaired NAWL's Uniform Divorce Reform Committee in the 1950s, also chaired NAWL's Committee on Jury Service in 1947.286

283. NAWL representatives were prominent among those relatively few women's organizations that testified in favor of the ERA in front of the Senate Judiciary Committee. See "Hearings on the Equal Rights Amendment to the Constitution and Commission on the Legal Status of Women, Before Subcomm. No. 1 of the House Comm. On the Judiciary," 80th Cong., 2d Sess. (1948) (Burnita Shelton Matthews, Chairman, NAWL's Committee on the Legal Status of Women and Rosalie M. Moynahan testified on behalf of NAWL in favor of the ERA). The women lawyers of NAWL did not all take the same position. Illinois members were on record as opposing the ERA and actively worked to defeat it, in part because of its potential to tear down the achievements of "good work of more than half a century" in the form of protective labor laws for women. "North East West South," Women Lawyers Journal 32 (1945): 164-65. Progressive organizations favored the Women's Status Bill instead, as an alternative to the ERA. Katherine M. Franke, "The Central Mistake of Sex Discrimination Law: The Disaggregation of Sex from Gender," University of Pennsylvania Law Review 144 (1995): 1, 17-18.

284. See, for example, Women Lawyers Journal 33, No. 1 (1947), which included an article by Matilda Fenberg, later chair of the Uniform Divorce Reform Committee, on "Jury Service for Women"; Ruth Wood's initial article on "Marriage and Divorce Law" published at an early stage of the divorce reform project; an editorial on the Administrative Procedure Act; Dorothy Kenyon on the "United Nations Commission on the Status of Women"; professional news; "Legal Problems of Artificial Insemination"; "Recent Amendments to the National Service Life Insurance Act"; "New York State Law Against Discrimination"; "One Hundred Years of Women in the News"; and a list of NAWL Committees.

285. See, for example, Matilda Fenberg, "Jury Service for Women," 11 (naming jury service as NAWL's number one priority), note 4. In 1931, along with Alice Paul's National Women's Party NAWL also sought leave to file an amicus brief in an unsuccessful bid to have the Supreme Court review the issue of female jury exclusion. See "Motion of National Association of Women Lawyers for Leave to File Brief As Amicus Curiae and Brief as Amicus Curiae," note 4. Jury service also was a priority issue for the League of Women Voters, an organization on the other side of the ERA divide. Linda Kerber, No Constitutional Right To Be Ladies (1998), 144.

286. Fenberg, "Jury Service for Women," 11, note 4. 
Fenberg also was a prominent NAWL spokeswoman on the ERA. ${ }^{287}$ Jury service was a natural corollary of the fight for suffrage and full citizenship under the law. ${ }^{288}$ The issue persisted throughout the "doldrums" years, finally taking on a new shape in the 1960s under the influence of Dorothy Kenyon and Pauli Murray and their more radical civil rights perspective. ${ }^{289}$ Judge Kenyon was "outspoken" in her opposition to the ERA. ${ }^{290}$ Yet she maintained her long-time NAWL membership and chaired that organization's Committee on International Relations after World War II. ${ }^{291}$ To a degree, then, NAWL provided a big professional tent for activist women who were not defined exclusively by their position on the ERA. ${ }^{292}$

287. In 1944, NAWL sent her to lobby the Republican National Convention for a plank endorsing the ERA. "The President's Page," Women Lawyers Journal 30 (1944): 20.

288. See, for example, Sarah T. Hughes, "The Half Citizen," Texas Bar Journal 2 (1939): 99. See also "Motion of National Association of Women Lawyers for Leave to File Brief As Amicus Curiae and Brief as Amicus Curiae," note 4 (laying out argument based on the similarity of the language of the Nineteenth and Fifteenth Amendments).

289. When the Supreme Court agreed to take up the issue of female jury service exclusion in Hoyt v. Florida, 368 U.S. 57 (1961), the American Civil Liberties Union recruited Kenyon to write their first-ever amicus brief in support of a women's rights issue. "Brief of the Florida Civil Liberties Union and the American Civil Liberties Union, Amici Curiae," 1961 WL 102288 (Appellate Brief), Hoyt v. Florida, 368 U.S. 57 (1961) (No. 31). The brief made an argument based on Fourteenth Amendment Equal Protection jurisprudence, including recent precedents from Brown v. Board of Education, 347 U.S. 483 (1954), and, especially, Hernandez v. Texas, 347 U.S. 475 (1954). Kenyon argued that Hernandez, which involved jury exclusion of Mexican-Americans (who were considered white by law), demonstrated that exclusion of a group "far beyond the limited realms of race or color" could violate equal protection. "Brief of the Florida Civil Liberties Union and the American Civil Liberties Union, Amici Curiae," 1961 WL 102288 (Appellate Brief) at *11. Although the Hoyt challenge was unsuccessful, Kenyon and prominent black activist Pauli Murray famously used the argument later to defeat the systematic exclusion of black men in practice and the statutory exclusion of women from state juries. White $v$. Crook, 251 F. Supp. 401 (M.D. Ala. 1966). See Marguerite Rawalt, "Jury Service for Women-A Constitutional Right within the Fourteenth Amendment," Women Lawyers Journal 52 (1966): 50 (reporting on White v. Crook). (The lawsuit was filed after the murders of civil rights workers Viola Liuzzo and Jonathan Daniels after the Selma-toMontgomery march of 1965.) The Supreme Court did not strike down female jury exclusion until the American Civil Liberties Union (ACLU)'s Women's Rights Project prevailed in Taylor v. Louisiana, 419 U.S. 522 (1975). Thus, in the person of Dorothy Kenyon, the jury service issue represents an arc of continuity and transition from the old-line feminist organizations such as NAWL to the civil rights and gender activism of the 1960s.

290. Muriel E. Richter, "Lawyers in the News," Women Lawyers Journal 35 (1949): 25.

291. Selma Moidel Smith, "The International Committee and NAWL's History of Involvement," Women Lawyers Journal 97 (2012): 9-12.

292. For another example of NAWL's big tent, see also Miriam Lashley, "Membership Drive Going Into High Gear," Women Lawyers Journal 45 (1959): 12 (reporting on the push for additional NAWL membership in Michigan led by labor law attorney Anne 
In the end, NAWL's function as a national professional outlet for beleaguered women attorneys suggests a different kind of link between their commitment to women's rights and their divorce reform project. Because of pervasive sex discrimination, female attorneys found it difficult to gain a toehold in the profession. ${ }^{293}$ They were so invisible that it was difficult to obtain an accurate count of women lawyers in the 1950s.294 Therefore, the women resorted to separate professional organizations such as NAWL. ${ }^{295}$ Moreover, in contrast to their male counterparts, women lawyers in the mid-twentieth century chiefly specialized in divorce law, which was still true later during the years of the no-fault divorce revolution. ${ }^{296}$ As Louise Raggio, the "dean" of Texas family lawyers and an active NAWL member explained, female attorneys were routinely denied opportunities outside of a narrow range of fields such as family law, a specialty that was among the "least-esteemed of the types of law practice, and thus more easily open to women." ${ }^{297}$ This channeling effect can be seen in the roster of NAWL's members. For example, in 1946-47, the NAWL Committee on Domestic Relations boasted individual members from

R. Davidow). Davidow practiced law under her maiden name and in partnership with her brother. Their firm was counsel to the Reuther brothers and the newly formed United Auto Workers (UAW.) She was "a self-proclaimed life-long feminist" who represented a class of women excluded from the bartending occupation because of their sex by a postwar "reconversion" statute. Goesaert v. Cleary, 335 U.S. 464 (1948). www.micourthistory.org/ women-and-the-law/anne-davidow (April 18, 2014).

293. See Drachman, "The New Woman Lawyer," 241-42, note 1 (describing how between 1899 and the 1930s, juvenile courts and even "women's courts" around the turn of the nineteenth century gave women lawyers and judges their first professional inroads).

294. See note 120.

295. Drachman, "The New Woman Lawyer," 245, note 1.

296. For the concentration of women lawyers in domestic relations fields, in the 1950s, see Raggio, "Women Lawyers in Family Law," 503, 510, note 12 (describing limited opportunities in 1952 when she began to practice law); Janet Taber, Marguerite T. Grant, Mary T. Huser, Rise B. Norman, James R. Sutton, Clarence C. Wong, Louise E. Parker, and Claire Picard, "Project Gender, Legal Education and the Legal Profession: An Empirical Study of Stanford Law Students and Graduates," Stanford Law Review 40 (1988): 1209, 1210-11 (family law practice in 1960 was one of the limited areas of practice open to the few women and ethnic and racial minority attorneys); James J. White, "Women in the Law," Michigan Law Review 65 (1967): 1051, 1062 (results of his survey show that women predominate in fields of trusts and estates and domestic relations whereas men dominate corporate, real estate, litigation, criminal, and labor fields); and Richard J. Maiman, Lynn Mather, and Craig A. McEwen, "Gender and Specialization in the Practice of Divorce Law," Maine Law Review 44 (1992): 39 (survey of Maine and New Hampshire demonstrates that female lawyers devote more of their practice to divorce law than their male counterparts).

297. Raggio, "Women Lawyers in Family Law," 503, note 12. Raggio recounted her own experience in 1952, when there was "no major firm in Dallas who would hire a woman lawyer." Ibid., 510. 
nearly three quarters of the states and the District of Columbia, and there was just a slightly smaller section for juvenile law. ${ }^{298}$ The only committee that exceeded this size was the one on "Jury Service for Women." 299 The dozens of committees covering many other legal specialties were all significantly smaller, including the Legal Status of Women section that focused on the ERA. ${ }^{300}$ These committee memberships provide some evidence of the opportunities and interests of women lawyers in the 1950s. It is clear why their expertise in family law was particularly important to the professional identity of women lawyers and to the members of NAWL. Louise Raggio maintained that family law was "a part of the history of women emerging as political beings in the United States." ${ }^{301}$ She argued that "the movements to abolish slavery, to get the right to vote, and to enact humane laws affecting the family are all intertwined and should be considered together." ${ }^{302}$ Raggio also observed that the ABA finally permitted NAWL to become one of its auxiliary legal organizations in 1943, when wartime changes in the profession were occurring. ${ }^{303}$ In the words of Raggio, when NAWL "got their 'vote and voyce' [in the ABA] [they] ... used this as a "bully pulpit" to further their programs." 304

As has been discussed, NAWL's aspiration to influence the making of divorce law policy was thwarted. NCCUSL refused to consider NAWL's bill unless it was submitted by a section of the ABA. NAWL then labored successfully for the establishment of the Family Law Section. ${ }^{305}$ Even then, however, the commissioners sidestepped the women lawyers' bill entirely. NCCUSL undertook divorce reform only after elite male

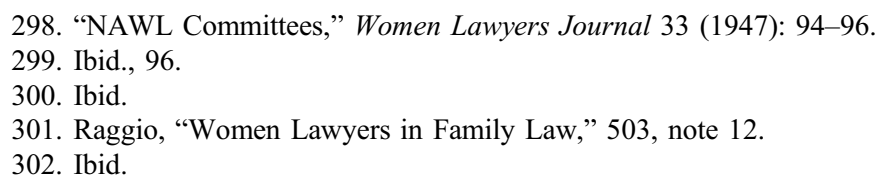

303. Ibid., 503. See also Smith, "A Century of Achievement: The First 50 Years," 10, note 48 ("formal recognition of NAWL and women lawyers by the ABA" was "accomplished by NAWL president Marguerite Rawalt in 1943," entitling it to a seat in the ABA House of Delegates). "For decades, NAWL was the voice for organized women lawyers in the ABA House of Delegates." Smith, "A Century of Achievement: The Second 50 Years," 30, note 5. NAWL President Grace B. Doering was the first woman elected to the ABA Assembly. Ibid.

304. Raggio, "Women Lawyers in Family Law," 510, note 12.

305. Ibid., 512. A charter member of the section, Louise Raggio explained that once the Family Law Section was established "[b]ecause many women lawyers were practicing family law, many Section members were female, but its officers, the Section leadership, except for the office of secretary, were always men." Ibid. "Neva Talley of Arkansas had been Section secretary for seven years by 1969 and had been the hardest working person in the Section, but the nominating committee would never let her rise to be Chair, because that was "a man's job." Ibid. 
matrimonial lawyers decided to address it. In its own way, then, the story of NAWL's campaign demonstrates the continuity of women's activism in the "doldrums" era. It shows that even a so-called "core" and "elite" women's rights organization could have an agenda that was not centered on the ERA and that was impeded by the marginalization of women within their own profession. This study of NAWL and its "greatest campaign" teaches us about the history of divorce, the limits of the domesticity paradigm, and the continuity of women's activism in the doldrums. It is a lost chapter well worth recovering. 